
Yil 15
Güz 2017
Sayı 23
Ss. 265-295

Geliş Tarihi: 11.09.2017

Kabul Tarihi: 11.10.2017

\title{
Troas Bölgesi’ndeki Antik Granit Ocakları: Yeni Bulgular*
}

\author{
Murat AY** \\ Veysel TOLUN ${ }^{* * *}$
}

$\ddot{O} z$

Buçalışma Kuzeybatı Anadolu'da Biga Yarımadası 'yla sınırlandırllan, Antik Çağ'da ise Troas olarak adlandırllan, günümüz Çanakkale Ili, Ezine İlçesi sınırları içerisinde yer alan Çı̆̆r Dă̆l ve çevresindeki Roma Imparatorluk Dönemi'nde işletilen antik granit ocakları üzerine bir değerlendirmedir. Tespit edilen antik granit ocakların barındırdı̆̆ üretim izleri ve kalıntıları dikkate alınarak üretim faaliyetleri ile bu ocaklardan çıkarılan yekpare sütunların üretim teknikleri incelenmektedir. Bunun yanında bu ocaklarda üretilen sütunların Aleksandreia Troas limanına hangi yöntemler kullanılarak taşındı ğ irdelenmektedir Ayrıca Troas granit ocaklarının işletildiğ $i$ dönemsel aralığ belirlemek ve bu ocaklardaki üretimin durması ile ihraca hazır hale getirilmiş olan sütunların terkedilmelerindeki olası faktörler irdelenmektedir.

Anahtar Kelimeler: Troas, Antik, Granit Ocăğ, Sütun.

\section{Ancient Granite Quarries in Troad: New Findings}

\section{Abstract}

This study represents a reassessment of the Roman granite quarries located around Mount Çı̆gr in the Ezine district of Çanakkale Province in northwestern Turkey, which corresponds to the ancient region of the Troad in antiquity. Activities and techniques related to the production of monolith columns such their extraction from the quarries have been closely evaluated by examining the work scars and traces of tool use observed on both the columns and the waste-by products related to their production identified over the surface of these quarries. In addition to, have been

* Bu çalışma Çanakkale Onsekiz Mart Üniversitesi Bilimsel Araştırma Projeleri Koordinasyon Birimince desteklenmiştir. Proje Numarası: 521.

** Murat AY, Arş. Gör. Çanakkale Onsekiz Mart Üniversitesi, Fen-Edebiyat Fakültesi, Arkeoloji Bölümü, muratay@comu.edu.tr.

*** Veysel TOLUN, Yrd. Doç. Dr. Çanakkale Onsekiz Mart Üniversitesi, Fen-Edebiyat Fakültesi, Arkeoloji Bölümü, vtolun@comu.edu.tr. 
examined which methods are used to transport the columns produced in these quarries to the harbor of Alexandria Troad. Moreover, when these quarries begun to be used and abandoned during the Roman period are also discussed here, while the causes of abandonment of the quarries and the complete columns ready to be shipped are also evaluated in light of the present evidence.

Keywords: Troad, Antiquity, Granite Quarry, Column. 


\section{Giriş}

Günümüz Biga Yarımadası'nı kapsayan Troas Bölgesi'ndeki (Harita 1) granit ocakları Çanakkale İli, Ezine İlçesi sınırları içindeki, 520 metre rakımlı Çığrı Dağı'nın çevresinde yer almaktadır (Harita 1).

Bölgedeki antik ocaklar günümüze kadar birçok araştırmacı tarafından ziyaret edilmiştir. Ocaklar ilk kez 1853 yılında bölgeyi gezen C. T. Newton tarafından ziyaret edilmiştir. Newton, Koçali Köyü yakınlarındaki antik granit ocağında bulunan 7 adet yekpare sütunu 'Yedi Taşlar' olarak adlandırmıştır (Newton 1865: 128). H. Schliemann ise bölgede 1879 yılında başladığı araştırmalarda Kestanbol (Uluköy) yakınlarındaki ocağı tespit etmiştir (Schliemann 2014: 25). Bölgede 1960 - 1970 y1lları arasında araştırma yapan J. M. Cook da antik granit ocaklarından bahsetmektedir (Cook 1973: 14, 209). Bölgedeki ilk yerel çalışma 1977 yılında, dönemin Çanakkale Arkeoloji Müzesi'nin müdürü M. A. Işık tarafından gerçekleştirilmiştir. Işık, Koçali ve Akçakeçili Köyleri yakınlarında bulunan Koçali ve Akçakeçili Ocağı'nı ve bu ocaklardaki sütunları incelemiştir (Işık 1977: 125-135). Troas granit ocakları hakkında en kapsamlı araştırmayı ise 1993 yılında "Troia Projesi”" kapsamında geniş bir ekiple G. Ponti gerçekleştirmiştir. Ponti ve ekibi, bölgedeki Koçali ve Akçakeçili ocaklarının planlarını çıkarmış ve ayrıca bu ocaklardaki sütunların çizimlerini ve bölgedeki antik ocakların bulunduğu alanın topografik haritasını hazırlamıştır (Ponti 1995: 291-320).

$\mathrm{Bu}$ çalışmada G. Ponti'nin gerçekleştirdiği çalışmada değindiği konulara ek olarak bölgedeki ocaklarda görülen sütun üretim teknikleri, çıkarılan sütunların Aleksandreia Troas limanına taşınmasında kullanılan yöntemler ve ocakların terkedilmelerindeki nedenler irdelenmiştir.

Aleksandreia Troas'1, 1786 yılında ziyaret eden Fransız bilim adamı J. B. Le Chevalier bölgedeki granit sütunlardan bahseder (Le Chevalier 1791: 8, 26, 30). Troas granit ocaklarında üretilen sütunlar ilk olarak M. G. F. A. Choiseul-Gouffier'ın talebi üzerine Fransız ressam L. F. Cassas'ın 1786 yılında çizdiği Aleksandreia Troas'a ait planda (Resim 1) belgelenmiş olup, daha sonra Fransız ressam L. J. J. Dubois'in 1814 yılında hazırlamış olduğu kentin limanına ait plan üzerinde gösterilmiştir (Resim 2). Schliemann da bölgede birçok granit sütun olduğunu aktarır (Schliemann 2014: 2073). Cook, Koçali Köyü yakınlarındaki, günümüzde 'Yedi Taşlar' olarak da bilinen ocaktaki büyük çaplı yekpare granit sütunların varlığından bahseder (Cook 1973: 14).

Troas graniti Roma İmparatorluk Dönemi'nde Marmor Troadensium olarak bilinmektedir (Reynolds - Ward Perkins 1952: 132, no:467; Gnoli 1971: 126). Troas graniti 16. yüzyılda Scalpellini tarafından Granito Violetto (Menekşe renkli granit) olarak adlandırmıştır (Gnoli 1971: 126; Ponti 1995: 292; Albustanlıoğlu 2011: dn. 45). L. Lazzarini, yaptığı araştırma sonucunda Troas granit sütunlarının mineralojik - petrografik yapısını inceleyerek Troas granitinden üretilen sütunların dağılımı ile ilgili uzun bir liste hazırlamıştır (Lazzarini 1987: 157-172).

İlk olarak Arkaik Dönem'de Neandriea'nın inşa faaliyetleri için kullanılmış olan ocaklar, Hellenistik Dönem 'de Aleksandreia Troas'ın kurulmasıyla birlikte artan üre- 
tim ihtiyacını karşılamış olmalıdır. Troas granit ocaklarının ilk işletilmeye başlandığı tarih, Neandriea'nın savunma duvarlarının tarihlendiği M.Ö. 5. yüzyıl olarak önerilmektedir (Gnoli 1971: 152, 153; Cook 1973: 14; Mielsch 1985: 68; Galetti - Lazzarini vd. 1992: 168; Ponti 1995: 291-320). Troas granit ocaklarının Klasik Dönem'de yerel ihtiyacı karşılamak için kullanıldığı, Roma İmparatorluk Dönemi'nde ise bu ocaklarda üretilen sütunların Akdeniz Havzası'ndaki kentlere ihraç edildiği bilinmektedir (Gnoli 1971: 152, 153; Cook 1973: 14; Ward Perkins 1980: 49; Lazzarini 1987: 157172; Dodge 1988: 65-80; Ponti 1995: 291-320; Feuser 2011: 256-273; Pensabene - Rodà vd. 2015: 318).

Troas granit ocaklarının kaydı ya da mutlak tarihlendirmesi olmadığı için (Ponti 1995: 316) bölgedeki ocakların işletildiği tarihi kabaca M.Ö. 500 ile M.S. 500 arasına yerleştirilmektedir (Feuser 2009a: 16-17). Aleksandreia Troas kalıntılarını kaplayan tortullardan alınan 4 kömür örneğinin ${ }^{14} \mathrm{C}$ analizi, ocaklardaki üretimin en geç M.S. 395 tarihinden önce durdurulduğunu düşündürmektedir (Yavuz 2014: 395). Aleksandreia Troas kazılarında bir tahrip tabakasından alınan kömür parçasından sıkıştırılmış ayarl1 ${ }^{14} \mathrm{C}$ tarihlemesine göre bu zaman aralığının Aleksandreia Troas'ın kurulduğu M.Ö. 310 ile M.S. 410 arasında olduğunu işaret eder (Haudenschild 2011: v). Bölgedeki ocaklarda tespit edilen üretim izleri ve çıkarılan sütunların boyutları bu ocakların Roma İmparatorluk Dönemi'nde işletilmiş olduğunu işaret eder (Russell 2013: 207). Ancak bu tarihi sınırlamalar taş ocaklarının tarihi ve ekonomik bağlamı hakkında ayrıntılı bilgi imkanı sunmamaktadır. Cook ve Işık da günümüze ulaşan Koçali ve Akçakeçili ocaklarını ve bu ocaklarda terkedilmiş haldeki büyük çaptaki yekpare sütunları Geç Roma Dönemi’ne tarihlemiştir (Cook 1973: 209; Işık 1977: 128).

Troas granit ocaklarında üretilen döşeme taşları ve sütunların ihracı Hadrian Dönemi (M.S. 117-138) ile yaygınlık kazandığı bilinmektedir (Pensabene 1998: 337338; Agus - Cara vd. 2007: 389). Bu ocaklar M.S. 2. yüzyılda neredeyse yalnızca yekpare sütun üretimi için işletilmiştir (Russell 2013: 88). Bölgedeki ocaklarda üretilen sütunların en yaygın kullanımının Roma İmparatorluk Dönemi’nde olduğu önerilmiştir (Galetti - Lazzarini vd. 1992: 168, Tab. 1). Russell, bu ocakların Geç Roma - Erken Bizans Dönemi’nde işletildiğini ileri sürer (Russell 2013: 207). Ayrıca hem Romalıların hem de Bizanslıların Troas granitini ödüllendirdiği aktarılmıştır (Sodini 2002: 131). Bu durum Troas granit ocaklarının Bizans İmparatorluğu Dönemi’nde de işletildiğine işaret etmektedir.

A. M. Hirt, imparatorluk idaresince M.S. 3. yüzyılın ortasına kadar işletilen ocaklar ile ilgili yapmış olduğu çalışmada Troas granit ocaklarını imparatorluğa ait ocaklar içerisinde değerlendirmez (Hirt 2010: 10-32). Cook ise bu ocakların Geç Roma Dönemi'nde imparatorluk mülkiyetinde olduğunu belirtir (Cook 1973: 209). G. Borghini de Geç Antik Çağ'a tarihlendirdiği ocakların imparatorluğa ait olduğunu savunur (Borghini 1989: 237). Ayrica İmparator Theodosius'un M.S. 414 ve 416 yıllarında yayınladığ1 iki kararnamede (Codex Theodosianus XI. 28, 9, 11) Troas ocaklarının imparatorluk idaresince işletilmiş olduğu anlaşılmaktadır (Gnoli 1971: 127; Monna - Pensebene 1977: 173; Dworakowska 1983: 99; Borghini 1989: 237; Fant 1989: 11). 
Troas granit ocakları Anadolu'da imparatorluk idaresince yazıtsız üretim yapan ocaklar içinde yer alır (Albustanlığlu 2013: 59). Bu ocaklarda üretilmiş sütunlar üzerinde herhangi bir yazıt bulunmayışı nedeniyle bu ocakların işletme düzeni ve organizasyonu hakkında yeterince bilgi edinilememektedir. Benzer şekilde Roma'da önemli bir yere sahip olan Mısır'daki Mons Claudianus Ocağı'nda da yazıt bulunmamaktadır (Albustanlığlu 2011: 29, dn. 45). Bu durumun olası nedeni, bu iki önemli granit ocağındaki üretim ve ticaretin imparatorluk idaresince gerçekleştirilmiş olmasıdır. Ayrıca yazıtların genellikle renkli mermerler üzerinde yer alması (Asgari - Drew Bear 2002: 17) nedeniyle Troas ve Mons Claudianus Ocakları ile bu ocaklardan çıkarılan sütunların ve blokların üzerinde herhangi bir yazıt olmamasının nedeni olabilir.

\section{Koçali Ocağı}

Koçali Ocağı, Çanakkale ili Ezine ilçesinin 16 km güneybatısında yer alan Koçali Köyü'ne doğru giden yol üzerinde, köye 500 m mesafede olup yolun sol tarafinda yer almaktadır (Harita 1). Troas Bölgesi'ndeki ocaklardan en bilindik olanı 'Yedi Taşlar' olarak da tanınan Koçali Köyü yakınlarındaki bu ocaktır. Koçali Ocağı'na giden patika yol üzerinde, ocağa $100 \mathrm{~m}$ mesafede 2 adet yekpare sütun bulunmaktadır. İlk bakışta bu sütunların çıkarıldıkları ocağın önünde bulundukları gözden kaçar ve genellikle Koçali Ocağı'ndan buraya taşındığı düşüncesi oluşur. Fakat çevreye biraz dikkatli bakıldığında, ortalama $11 \mathrm{~m}$ uzunluğundaki, alt çapları $1.65 \mathrm{~m}$, üst çapları ise $1.35 \mathrm{~m}$ olan bu sütunların çıkarıldıkları ocağın hemen karşısında terkedilmiş olduğu görülebilmektedir (Resim 3). Sütunların kaideleri $30 \mathrm{~cm}$ kalınlığında olup içe doğru 4 cm'lik bir girintiye sahiptir. Sütunların üst kısımları ise iki kademeli bir başlık şeklinde işlenmiştir. Başlıkların birinci kademesi $7 \mathrm{~cm}$, ikincisi ise $28 \mathrm{~cm}$ yüksekliğe sahiptir. Koçali Ocağı'na giden patika yolun kenarında bırakılmış olan sütunlarda herhangi bir tahrip izi ve üretim hatası olmadığı anlaşılmaktadır. Ocağın kendisi ve bulunduğu alan detaylı bir şekilde incelendiğinde, bu ocaktan çıkartılmış sütun say1sının daha fazla sayıda olması gerektiği fikri oluşur. Bu durum ilk başta bölgede ihraç edilecekleri liman güzergahına ait yol üzerinde terkedilmiş olan sütunların bu ocaktan taşınmış olabileceğini düşündürmektedir. Bu iki sütunun bulunduğu alandan tepeye doğru uzanan patikadan yaklaş1k $100 \mathrm{~m}$ ileride bulunan esas sütun üretim yeri olan Koçali Ocağı bulunmaktadır (Resim 4; Çizim 1, 2). Güneydoğu-Kuzeybatı doğrultusunda açılmış olan ocağının yatağı batıya doğru 200 m'lik bir alanı kapsamaktadır. Koçali Ocağı'nın içerisinde 7 adet sütun bulunmaktadır. Bu sütunların 4'ü günümüze tek parça halinde ulaşmıştır. Bu sütunlar ortalama $11 \mathrm{~m}$ uzunluğunda, üst çapları ortalama 1.65 m, alt çapları ise 1.35 m ölçülerindedir (Çizim 3). Koçali Ocağı'ndaki tahrip görmemiş bu devasa boyutlardaki yekpare sütunların ölçüleri, ocağa gelen yol üzerindeki, Akçakeçili Ocağı'ndaki ve çevrede tespit edilen sütunlar ile hemen hemen aynı ölçülerdedir.

Koçali Ocağı'ndaki sütunların 3 tanesinin alt ve üst bölümlerinde kama izleri ve kırıklar mevcut olup uğradıkları bu tahribat sonrası gerçek uzunluk ölçülerini kaybetmiş durumdadırlar (Resim 5). Tahrip edilmiş haldeki bu 3 sütunun uzunlukları sırasıyla 8.15 m, 8.30 m ve 5.95 m'dir. Ocağın içindeki bu kırık sütunların üzerindeki 
kama izlerine bakıldığında modern zamanlarda müdahale edildiği anlaşılmaktadır. Bu müdahaleler, olasılıkla değirmenlerde ögütme taşı ya da zeytin yağı üretimi için pres taşı olarak kullanmak amacıyla yerli halk tarafından yapılmış olmalıdır.

\section{Akçakeçili Ocağı}

Akçakeçili Ocağı, Koçali Köyü’nün 7 km güneybatısında, Akçakeçili Köyü'nden 500 m uzaklıkta, Alemşah Köyü'ne doğru devam eden yolun 200 m doğusunda bulunmaktadır (Harita 1). Bu ocak bölge sakinleri tarafından 'Direk Taşlar Mevkisi' olarak adlandırılmış olup (Işık 1977: 127), literatüre 'Kestanbol' olarak geçmiştir (Ponti 1995: 291-320). Günümüzde ise ocağın bulunduğu alan 'Sığırasarı Tepesi' olarak bilinmektedir. Düz bir alanda yükselen granit oluşumun içinde yer alan ocak ve çevresi günümüzde büyük ölçüde bodur meşelerle kaplıdır (Resim 6).

Akçakeçili Köyü yakınlarında yer alan ocak Koçali'den sonra en önemli ocaktır. Ocak alanının bittiği alanda günümüzde neredeyse tamamen kurumuş olan Büyüdüz Çay1 geçmektedir (Iş1k 1977: 127). Günümüzde bu akarsu Değirmen Dere olarak adlandırılmaktadır (Tombul 2015: 423, 460, 461). Ocak ve çevresi, sütunların üretimi hakkında bilgi sahibi olmamızı sağlayan izler barındırmaktadır. Sütunların çıkarıldığı ocağın yüzeyindeki kama izleri, Koçali Ocağı'nın yüzeyinde de görülen paralel şeritler halindedir.

Kestanbol olarak da bilinen bu ocağı ilk tespit eden araştırmacı olan Schliemann, ocakta 9 adet sütun olduğunu belirtmektedir (Schliemann 2014: 25). Akçakeçili Ocağı'ndaki ilk yerli araştırmayı yapan Işık’ta ocakta 9 adet sütun yer aldığını aktarmıştır (Işsk 1977: 126). Ponti ise bu ocakta 11 adet sütun bulunduğunu tespit etmiştir (Ponti 1995: 310), (Çizim 4). Bu sütunların 7 adeti günümüze büyük ölçüde hasar görmeden ulaşmıştır. Sütunların diğer 4 tanesi ise alt ve üst bölümlerinden koparılma girişimleri sonucu tahribata uğramıştır.

Akçakeçili Ocağı'ndaki sütunlar da Koçali'deki sütunlarla aynı ebat ve şekildedirler. Ayrıca ocağın içerisinde düzgün kesilmiş ve kesimi yarım kalmış bloklar bulunmaktadır. Bu yarı işlenmiş bloklardan ikisi olasılıkla daha ufak ebatlarda sütun elde etmek için kesilmiştir (Resim 7). Ocağın içindeki kırık veya tahrip edilmiş sütunların üzerindeki kama izlerine bakıldığında modern zamanlarda müdahale edildiği anlaşılmaktadır. Ocağın güneyindeki 'Ev Kayası Mevkii'nde yarım kalmış bloklar ve mimari kalıntılara rastlanmaktadır (Tombul 2015: 423.). Bu alanda görülen konut izleri, buranın olasılıkla taş ocağı işçilerinin barındığı bir kamp alanı olduğunu düşündürmektedir.

\section{Bölgedeki Diğer Ocaklar}

Çığrı Dağ'1 çevresinde antik taş ocağı faaliyetlerine ait izler yaygın bir şekilde görülmektedir. Ponti, Neandriea'nın kurulu olduğu Çığrı Dağı yamaçlarında, Koçali ve Akçakeçili ocaklarından farklı olarak daha ufak boyutlarda sütun üretimi yapılmış olan antik ocaklar tespit etmiştir (Ponti 1995: 295). Bölgede yapılan yeni arazi çalışmalarında keşfedilen antik sütun üretim ocaklarına özellikle Koçali ve Akçakeçili 
ocaklarının çevrelerinde rastlanmaktadır. Akçakeçili ocağı yakınlarında keşfedilen antik sütun ocağında günümüze kadar korunarak ulaşan üretim izleri, üretim yöntemleri hakkında kapsamlı bilgiler edinmemizi sağlamaktadır (Resim 8).

Bölgede en bilindik ocak olan Koçali çevresinde yer alan Turplu Tepe ve Yarıktaş Tepe'deki ocaklar da (Ponti 1995: 302, 303) antik üretim izlerini barındırmaktadır. $\mathrm{Bu}$ iki ocak da üretim olarak Akçakeçili ve Koçali ocaklarından farklı olarak daha ufak boyutlarda, uzunlukları $4 \mathrm{~m}$ ile $7 \mathrm{~m}$, çapları $48 \mathrm{~cm}$ ile $24 \mathrm{~cm}$ arasında değişen sütunların ve blokların üretimi için işletilmiş olduğunu gösteren buluntular yer almaktadir.

\section{Üretim Teknikleri}

Troas granit ocaklarında yapılan incelemelerde genel olarak sütun üretimi için oluk-kanal açma yönteminin tercih edildiği gözlemlenmiştir (Resim 8). Bunun yanısıra ocaklarda kamalar ile çatlatma yöntemiyle gerçekleştirilen üretim izlerine de rastlanmaktadır (Resim 9). Bu izler olasılıkla daha ufak çaptaki sütunların ve döşeme taşı olarak kullanılan blokların çıkarılmasında kullanılmıştır. Sütunların, ocaklardan yassı uçlu kamalar kullanmak suretiyle yontularak çıkarıldığını gösteren izler Koçali ve Akçakeçili ocaklarının yatak yüzeylerinde izlenebilmektedir. Ocakların aynalarındaki izlere bakıldığında yatay kazıma yöntemi ile açılan oluklara aşağıya doğru çakılan kamaların yardımıyla büyük blokların koparıldığı anlaşılmaktadır (Resim 10). Sütun üretiminde kullanılacak blokların ocaklardan merdiven şeklinde tabakalar halinde alındığını gösteren izler ocakların aynalarında görülebilmektedir (Resim 11). Çıkarılan yekpare bloklar oval ve orantılı bir şekil verilinceye dek yontularak, günümüz torna işlemine benzeyen bir zımparalama tekniği ile kullanıma hazır hale getirildiği anlaşılmaktadır. Ocakların içinde yer alan üretim atıklarından, kaba şekilde çıkarılan bloklara sonradan sütun formu kazandırıldığı anlaşılmaktadır. Troas'daki granit ocaklarında uygulanan sütun üretim yöntemine benzer biçimlerin, Prokonnesos'un Harmantaş ocağı ve Dokimeion ocaklarında uygulandığı bilinmektedir (Bingöl 2004: 30). Bu durum, aynı dönem içerisinde işletilen ocaklardaki sütun üretim tekniğinde benzer yöntemlerinin tercih edildiğini gösterir.

\section{Sütunların Taşınması}

Troas granit ocaklarında üretilen, yaklaşık olarak 60 ton ağırlığa sahip olan ve yaklaşık 40 Roma ayağı uzunluğundaki sütunların ihraç edildikleri, 13 km uzaklıktaki Aleksandreia Troas limanına nasıl taşındıkları da en çok sorulan sorulardan birisidir. İlk bakışta ocaklarda terkedilen sütunlar taşınamamalarıyla ilişkilendirilir.Ancak bu sütunların çıkarıldıkları ocaklardan oldukça uzak alanlarda görülmesi, sütunların ağırlıklarının ve ihraç edildikleri limana olan mesafenin uzaklığının taşıma işlemi için sorun olmadığının gösterir.

Sütunların taşınmasıyla ilgili somut veriler antik kaynaklar sayesinde günümüze ulaşmıştır (Vitruvius X. II: 2, 11, 12). Sütun silindirlerinin ve sütun tamburlarının taşınmasında farklı yöntemlerin kullanıldığ 1 belirtilmektedir (Landels 1996: 204). 
Fakat Troas granit ocaklarında da bulunan büyük çaplı sütunların nasıl taşındığına yönelik bir anlatım antik kaynaklarda geçmemektedir. Ayrıca bölgede yer alan ocakların bulunduğu alanın coğrafi yapısı ve sütunların ihraç edilecekleri limana olan mesafeleri göz ününe alındığında, bu ocaklarda Antik Çağ'da sütunların taşınmasında uygulandığı belirtilen yöntemlerden farklı bir yöntemin kullanılmış olduğu söylenebilir. Bu ağırlıktaki sütunların taşınmalarında hangi yöntemlerin kullanılmış olduğu kesin olarak bilinmemektedir. Bu boyutlardaki sütunların taşınma problemi iki farklı yöntem kullanılarak ya da iki farklı yöntemin bir arada kullanıldığg başka bir yöntem ile çözülmüş olabilir. Bunlardan ilki sütunların tomruklar üzerinden halatlar vasıtasıyla çekilerek yapılmasıdır. Diğeri ise sütunları kızaklara yerleştirerek taşınmasıdır. Bu iki yöntemin bir arada kullanımı da sütunların tomruklar üzerinde çekilen bir kızak üzerinde taşınmasıdır.

Sütunların taşınmasında çeşitli faktörler dikkate alınıyor olmalıydı. Bunlardan biri taşıma işlemi yapılacak sütunların çıkarıldıkları ocaklarda büyük ölçüde tamamlanmış olmasıdır. Öyle ki Koçali ve Akçakeçili ocaklarındaki sütunlar neredeyse tamamen işlenmiş durumdadır. Kaba yontuları yapılan mimari ögelerin başında yer alan sütun gövdeleri, bu işleme tabi olmalarıyla taşınma işlemlerinde kolaylık sağladığ bilinmektedir (Bingöl 2004: 34). Bunun dışında taşıma işlemi gerçekleştirilecek sütunların hasar görmeden kullanılacağı yapıya kadar taşınması da önemli bir sorundur. Sütunların taşıma esnasında uluşabilecek hasarın önlenmesi adına sütun gövdelerinde birkaç cm tıraşlanma payı bırakıldığı, sütunların alt ve üst çemberlerinde ise sütun gövdelerinin taşınırken hasar görmesini önlemek amacıyla yaklaşık $2 \mathrm{~cm}$ pay bırakıldığı bilinmektedir (Asgari - Drew Bear 2002: 8; Bingöl 2004: 36, 37). Bu çemberler, Koçali ve Akçakeçili ocaklarındaki büyük ölçüde tamamlanmış olan sütunların alt ve üst bölümlerinde yer almaktadır.

Söz konusu ocaklardan çıkarılan granit sütunların ihracı iki aşamada gerçekleşmekteydi. Öncelikle sütunların ihraç edilecekleri Aleksandreia Troas limanına kara yoluyla taşınması gerekiyordu. Daha sonra ise bu sütunların taşındıkları liman üzerinden sipariş edildikleri antik kentlere gönderilmek üzere gemilere yüklenerek ihracı gerçekleştiriliyordu. Limana taşınan sütunlar, muhtemelen üç ayaklı palangalar vasitasıyla gemilere yüklenerek (Aslan 1998: 88) Anadolu ve diğer imparatorluk eyaletlerindeki antik kentlere ulaştırılmıştır (Dworakowska 1983: 69; Aslan 1998: 89).

Troas ocaklarından çıkarılan devasa yekpare sütunların antik limana sevkiyatının kızak ya da tomrukların üstüne yerleştirilerek hayvan ve insan gücü ile kaydırılarak gerçekleştirildiği önerilmektedir (Aslan 1998: 88, 89). Sütunların kızak ile taşınma olasılığı, katedilecek mesafe ve ihtiyaç duyulan çekme kuvveti dikkate alındığında yalnız başına kullanışsız bir yöntem olarak gözükmektedir. Çünkü kızaklar üzerindeki sütunların çekilerek taşınmasında ortaya çıkacak olan sürtünme kuvveti, ihtiyac duyulan çekme kuvvetini de artıracaktır. İhtiyaç duyulan bu çekme kuvveti için farklı öneriler bulunmaktadır. V. A. Maxfield'a göre; Misır'daki Mons Claudianus ocaklarında çıkarılan 60 Roma ayağı ölçüsündeki bir sütunun taşınması için ihtiyaç duyulan çekme kuvveti ancak 200 deve ile sağlanabilmektedir (Maxfield 2001: 143-170). Diğer 
bir görüşte ise aynı ölçülerdeki bir sütunun taşınması için 400 katırın çekme kuvvetine ihtiyaç duyulacağı hesaplanmıştır (Adams 2001: 171-192).

Bir diğer öneri olarak tomruklar üzerinde taşıma yöntemi değerlendirildiğinde de sütunların tomruklar üzerinde sabit durması problemi ortaya çıkacaktır. Bölgenin engebeli ve eğimli arazi koşulları da göz önüne alındığında, taşıma esnasında ortaya çıkabilecek olası manevra sorunları nedeniyle sütunların zarar görmesi muhtemeldir. Bu nedenle Troas granit ocaklarında üretilen sütunların taşınmasına dair yeni bir bakış açısı getirmek gerekir. Bu durumda en kolay yöntem kızak ve tomruklar ile taşıma yönteminin bir arada kullanılması gibi gözükmektedir. Böylelikle hem çekme esnasında ortaya çıkan sürtünme azaltılmış olacak hem de yükün kontrolünün kaybedilmesi ve devrilmesi gibi sorunlar giderilmiş olacaktır. Ayrıca bu yöntem ihtiyaç duyulan çekme kuvvetini de azaltacağı gibi sevkiyatın daha kısa sürede gerçekleşmesine olanak tanımış olacaktır.

Koçali Ocağı'ndan antik limana uzanan doğrultuda yer alan Kemallı Köyü civarında, ocaktan yaklaşık $6 \mathrm{~km}$ uzaklıkta tespit edilen granit döşemeli antik yol ve bu yolun hemen kenarında bulunan yekpare sütun bu düşünceyi güçlendirmektedir (Resim 12). Ayrıca Aleksandreia Troas kentinin çevresinde aynı güzergaha ait olmas1 muhtemel olan iki adet aynı ebatlara sahip sütun daha tespit edilmiştir. Bu yol muhtemelen Koçali Ocağı ve çevresindeki ocaklarda çıkarılan sütunların taşınmasında kullanılıyor olmalıydı. Yahya Çavuş (Koçali) Köyü muhtarı Sezai Çubuk'un ifadesine göre bugün büyük bölümü toprak altında kalan yol, Kaz Dağı'ndan Dalyan Köyü'nde bulunan antik limana kadar uzanmaktadır (Çakıcı 2015: 175).

Akçakeçili Ocağı'nın bulunduğu bölgede herhangi bir antik yol izine rastlanmamıştır. Aleksandreia Troas'1 1678'de ziyaret eden Spon ve Wheller tarafından şehrin içlerine kadar sokulan dar ve uzun bir kanal olduğu aktarılmıştır (Texier 2002: 351). Bu ocağın Büyüdüz Çayı yatağına olan yakınlığı, Akçakeçili Ocağı'nda üretilen sütunların bu akarsuyun üzerinden tomruklar ile liman bölgesine taşınmış olabileceği düşüncesini akla getirir. Fakat bu kanal olasılıkla zamanla erozyon ve yağmur sularının getirdiği toprak ile dolduğundan dolayı günümüze ulaşamamıştır. Bu kanalın olası güzergahı üzerinde yer alan Ezine - Gülpınar yolunun olduğu bölgede, Akçakeçili Ocağı'nda üretilen sütunların ölçüleriyle örtüşen sütunlardan biri iki parça halinde bulunmuş olup, günümüzde Çanakkale Arkeoloji Müzesi'nin bahçesinde sergilenmektedir. Bu sütunun alındığı alanın 200 m batısındaki bir sulama kanalı kenarında, benzer ölçülere sahip başka bir sütun daha yer almaktadır.

Apollon Smintheus Kutsal Alanı ile Aleksandreia Troas kenti arasındaki antik yolda, Satnioeis (Tuzla Çayı) üzerinde, M.S. 1. yüzyıla tarihlenen bir Roma Köprüsü vardır. Bu köprünün kemerlerinin büyüklüğü ve yatağın 9 kemer ile ayrılmış olması, Tuzla Çayı'nın köprünün inşa edildiği dönemlerde taşıma kapasitesinin daha yüksek olduğunu düşündürmektedir. Ayrıca günümüzde Tuzla Çayı'nın yatak değiştirmiş olması ve debisinin hayli düşük olduğunun gözlemlenmesi Antik Çağ'dan günümüze bölgedeki akarsu yataklarının kurumuş olabileceği izlenimini vermektedir. Fakat bu konuda henüz herhangi bir çalışma ve somut veri olmayışından ötürü, sütunların 
akarsu yoluyla taşınmış olma olasılığı gözlemler yoluyla elde edilmiş bir çıkarımdan öteye gidememektedir.

\section{Ocakların Terkedilmesi}

Troas granit ocaklarındaki üretimin durması ve büyük oranda tamamlanmış sütunların büyük kısmının ocaklarda, bazılarının ise sütunların ihraç edildiği Aleksandreia Troas limanına doğru uzanan taşıma güzergahı hattında ve birkaçının da limanda ihraç edilmeye hazır şekilde terkedilmelerinin kesin nedeni bilinmemektedir. Bu konuda ileri sürülebilecek önerileri; Geç Roma Dönemi'nde Batı Roma İmparatorluğu'nun uğradığı saldırılar sonucunda ekonomik ve siyasi olarak kriz içinde bulunmas1, siparişlerin iptali, bölgede yaşanan şiddetli depremler ile bu depremler sonucunda oluşmuş olabilecek istila ve salgın hastalıklar olarak sayılabilir.

Anadolu Uygarlıklarının birçok önemli kentinin yıkılmasında depremler ön plana çıkar. Depremlerin yıkıcılığı dışında antik kentler üzerinde olan olumsuz ekonomik etkisiyle birlikte siyasi değişimlere sebep olmuştur (Karagöz 2005: 1, 2). Depremler; savunması zayıflayan, kaos içindeki kentlerin istilacıların hedefi haline gelmelerini kolaylaştıran bir faktördür. İstilaya uğrayan kentler ise zamanla önemlerini kaybederek tarih sayfasındaki yerlerini kaybetmişlerdir.

Ş. Karagöz, Batı Anadolu topraklarında, M.Ö. 800/700'den M.S. 600'e kadar y1kıcı depremlerin yaşandığını, bu depremlere ait bilgilerin yazılı kaynaklar ve mitolojik olaylar tarafından aktarıldığından bahseder (Karagöz 2005: 16). Troas Bölgesi'nde M.Ö. 287 yılında yaşanan şiddetli depremde tüm Hellespontos Bölgesi (Çanakkale Boğazı) ve özellikle Khersonnesos (Gelibolu) Yarımadası'ndaki Büyük İskender'in generallerinden Lysimakhos'un kurduğu Lysimakheia kenti'nin harap olduğu belirtilir (Sonnabend 1999: 142). Bölgeye yakınlığ 1 açısından önem arz etmekte olan Konstantinopolis'te ise M.S. 408 ve 447 y1llarında şiddetli iki depremin gerçekleştiği bilinmektedir (Grant 2000: 206). Kayıtlara M.S. 477 ya da 480 olarak geçen depremin 30 gün sürdüğü ve bütün Marmara Bölgesi'nin etkilediği, Abydos, Sestos, Kallipolis ve Lampsakos kentlerinin büyük zarar görmüş olduğu belirtilmiştir (Guidoboni 1994: 330). M.S. 500 tarihlerinde de bölgede iki şiddetli deprem yaşanmış, bu depremlerin sonucunda Troia büyük yıkıma uğramıștır (Blegen 1934: 110). Bu depremlerin daha şiddetli olan ikincisi sonrası kent terk edilmiş ve halkın büyük bir bölümü başka yerlere göç etmiştir (Rose 1992: 56). Araştırmacıların sismo-tektonik incelemeleri M.S. 6. yüzyılın ortalarında yaşanan bir deprem felaketinin Çanakkale yöresi ve Dardanos'u etkilediğini göstermiştir (Kayan 1997: 735-746).

Troia kentinin M.S. 6. yüzyılda geçirmiş olduğu iki kuvvetli depremin ardından terkedilmesi değerlendirilecek olursa, Aleksandreia Troas'ın da aynı depremler sonrasında büyük hasar görerek terkedilmesine yol açmış olabilir. Dolayısıyla bu durumda granit sütunların ihraç edildiği Aleksandreia Troas limanı da bu büyük depremler sonucu ağır hasar almış olmalıdır. Tüm bu veriler değerlendirildiğinde bölgenin üst üste gelen depremlerin yıkıcı etkisi yüzünden terk edilmiş olabileceğini ve bunun bir sonucu olarak da granit ocaklarındaki üretimin durmuş olabileceği söylenebilir 
Aleksandreia Troas ve limanının, olasılıkla M.S. 4. yüzyılda imparatorluğun yaşadığı ekonomik krize kadar önemini koruduğu, Çığrı Dağı çevresindeki taş ocaklarından çıkarılan granit sütunların ihraç edildiği önemli bir ticaret merkezi olarak kullanıldığ1 düşünülmektedir (Aslan 1998: 80). Roma İmparatorluğu'nun M.S. 395 yılında Doğu ve Batı olmak üzere ikiye ayrılmasıyla ortaya çıkan siyasi çekişmeler ile M.S. 5. yüzyılın ilk yıllarında başlayan saldırı ve istilalar siyasi ve ekonomik olarak büyük bir çöküşe neden olmuştur (Grant 2000: 44). Bu ekonomik çöküş ile birlikte imparatorluk idaresince işletilmeye başlanan Troas ocaklarındaki üretim de aniden durmuş olmalıdır. Büyük oranda Roma ve diğer imparatorluk eyaletlerine ihraç edilen sütunların üretiminin, söz konusu ekonomik kriz sonrası durduğunu ve ihraç edilmek için hazırlanan sütunların ise bu ekonomik krize bağlı olarak gerçekleşmiş olabilecek siparişlerin iptal edilmesi sonucu terkedilmiş olduğunu söylemek mümkündür. Işık, Troas ocaklarında üretilen sütunların ocaklarda, ihraç edildikleri liman güzergahı ve limanda terkedilmelerinin nedenini büyük bir devir değişikliği ile yani Bizans hakimiyetinin başlangıcı ile açıklamıştır (Işık 1977: 128).

Ayrıca bu dönemde yüzyıl öncesine nazaran, ekonomideki daralmaya paralel olarak mermer talebinde de büyük bir azalma söz konusudur (Albustanlıoğlu 2011: 29, dn. 45). Dworakowska, M.S. 5. yüzyılın başlarında Troas ocaklarındaki üretimin arttığına dair güvenilir kanıtların olduğu belirtilmiştir (Dworakowska 1983: 11, 26). Anadolu'daki taş ocaklarında yapılan arkeolojik araştırmalarda, M.S. 6. yüzyıldan sonra kullanıldıklarına yönelik kesin bir kanıt ele geçmemiştir (Dworakowska 1983: 26). Farklı bir görüş olarak C. Mango, Anadolu'daki taş ocaklarının çoğunun M.S. 6. ve 7. yüzyıllar da nüfusta görülen azalma ve ekonomik zorluklarla birlikte sona erdiğini (Mango 1976: 12-14), ancak buna rağmen bazı önemli mermer ocaklarının; örneğin Prokonnesos ve Dokimeion'da mermer üretiminin Orta Bizans Dönemi'ne kadar devam ettiğini ifade etmektedir (Mango 1972:161-165). Fakat Anadolu'daki taş ocaklarından elde edilen bulgular ise bunun aksine Orta Bizans Dönemi'nden önce ocak işletmelerin sona erdiğini göstermektedir (Ousterhout 2016: 154).

\section{Değerlendirme ve Sonuç}

Troas Bölgesi’ndeki ocakların M.Ö. 5. yüzyıl ile M.S. 5. yüzyıl arasında işletildiğini, Neandriea ve Aleksandreia Troas'ta kullanılan yapı taşlarından bilmekteyiz. Muhtemelen ilk olarak Arkaik Dönem'de Neandriea'nın inşasında kullanılmaya başlanılan granit ocakları, Hellenistik Dönem'de olasılıkla Aleksandreia Troas'ın kurulmasıyla ortaya çıkan taş ihtiyacını karşılamaya yönelik üretim gerçekleştirilmiştir. Fakat Aleksandreia Troas'da henüz Hellenistik yapılara ait bir kazı çalışması gerçekleşmemiş olduğundan somut bir kanıt bulunmamaktadır. Roma İmparatorluk Dönemi'nde ise Troas Bölgesi'ndeki granit ocaklarının yekpare sütunların üretimi ve ihracatında önemli bir merkez haline geldiği anlaşılmaktadır.

Akçakeçili ile Koçali ocaklarının üretim teknikleri ve üretilen sütunların ölçüleri birbirleriyle büyük oranda benzerlik göstermektedir. Bu benzerlik ocakların aynı tarihsel dönemde işletildiğine de işaret etmektedir. Bölgede bu iki önemli ocak dişında Antik Çăg' da işletildiklerini gösteren üretim izleri barındıran birçok ocak bulunmak- 
tadır. Bölgede yapılan gözlem ve incelemelerde, Akçakeçili ve Koçali granit ocakları ve çevrelerinde yoğun bir şekilde taş ocakçılığ faaliyetlerinin yapıldığını gösteren izler saptanmıştır. Bu ocaklarda üretilen malzeme türlerini genel olarak sütunlar oluştururken az miktarda zemin döşemesi için kullanılan blok üretimi de görülmektedir.

Bölgede yer alan granit ocakları incelendiğinde, Antik Çağ'da bu bölgeden ihraç edilmiş olan çok sayıdaki granit sütunların çıkarıldığını gösteren büyüklükteki ocaklar tespit edilememiştir. Bu durumun olası nedenleri, ocakların tamamen işletilmesinden dolayı günümüze ulaşmamış olmaları ya da bölgedeki geniş maki oluşumunun bu ocakları örtmüş olabileceği ihtimalidir.

Aleksandreia Troas'ın forum alanı ve liman bölgesinde birçok sütun ve blok parçası tespit edilmiştir. Aleksandreia Troas kazısının gerçekleştirildiği alanın kentin toplam büyüklügüünün $\% 5$ ' i kadar az bir bölümünü oluşturması, muhtemelen birçok granit buluntunun daha tespit edilebileceğini göstermektedir. Yine de Aleksandreia Troas'da granit kullanımını göstermesi açısından Decumanus Caddesi'nin inşasında kullanılan zemin döşeme taşları ve forum alanındaki sütunlar büyük önem arz etmektedir (Resim 13). Bu buluntuların tamamına yakını Roma Dönemi’ne ait olup Hellenistik yapılara ait granit kullanımı tespit edilememiştir. Bunun en büyük nedeni bu döneme ait yapıların kazılarının henüz gerçekleştirilmemiş olmasıdır. Kentin liman bölgesinde de birçok sütun ve blok parçası tespit edilmiştir. Fakat iç liman olarak kullanıldığı bilinen yapay limanın çevresinde yer alan birçok granit sütun ve blok parçası kum dolgu altında kaldığı görülebilmektedir. Kumlarla dolan iç liman ve çevresinin jeofizik yöntemleri ile taranmasıyla birlikte birçok sütun tespit edilebileceği öngörüsünde bulunmak mümkündür. Bu düşünceyi dış liman olarak kullanılan alanda görülebilen granit sütunlar (Resim 14) ve sualtı çalışmalarında (Feuser 2009b: 18-28; Feuser 2011: 256-273) tespit edilmiş olan granit sütunlara ve bloklara ait buluntular desteklemektedir (Resim 15). Ayrıca liman bölgesinde Aleksandreia Troas'1 Smintheion ve Assos ile bağlayan antik yola ait kalıntılar bulunmaktadır. Antik yolun zemin ve kenar taşları granitten üretilmiş olup günümüzde yolun ekseninde yer alan granit sütunlar in situ halinde görülebilmektedir (Resim 16).

Troas Bölgesi'ndeki Koçali ve Akçakeçili ocaklarında terkedilmiş haldeki yaklaşık 40 Roma ayağı uzunluğundaki yekpare sütunlarla aynı ölçülere sahip sütunların sevkiyat güzergahı ile ihraç edildikleri Aleksandreia Troas limanında bulunması, büyük oranda tamamlanmış haldeki sütunların ocaklarda bırakılması, probleminin taşınma zorluğu dışında diğer etkenlerden kaynaklanmış olduğunun göstergesidir.

Kemallı Köyü mevkiinde yer alan döşeme taşlı yol (Resim 17). olasılıkla Koçali Ocağı ve çevresindeki ocaklarda üretilen sütun ve blokların sevkiyat güzergahını oluşturmaktadır. Günümüzde büyük bölümü toprak altındaki bu yolun ortaya çıkarılması bölgenin turistik destinasyonu açısından önem arz etmektedir. Koçali Ocağı'nda üretilen sütunların sevkiyatının sağlandığı antik yolun uzantısının tespiti için bölgenin jeofizik yöntemi ile taranması ve sondaj kazılarının yapılmasına ihtiyaç duyulmaktadir. 
Akçakeçili Ocağı'nın muhtemel sevkiyat güzergahı hakkında ise bölgede herhangi bir yol tespit edilememiştir. Bu durum Akçakeçili Ocağı'nın önünden geçen, günümüzde kurumuş vaziyetteki Büyüdüz Çayı'nın sütunların taşıma işleminde kullanılmış olabileceği düşüncesini doğurmaktadır. Bu durumun tespiti için öncelikle ocağın önünden geçmekte olan yatağın, ocağın işletildiği dönemdeki debisinin hesaplanarak taşıma kapasitesinin ortaya konması gerekmektedir. Böylelikle yaklaşık olarak 60 ton ağırlığa sahip olan bu sütunların ocağın hemen bitiminde yer alan akarsudan faydalanılarak taşınıp taşınamadığı saptanabilir. Ayrıca bu akarsuyun olası yatak değişimi olup olmadığı da bölgede jeoarkeolojik yöntemler kullanılarak irdelenmesi gerekmektedir. Bu önerinin dışında Akçakeçili Ocağı'nda üretilen sütunların taşınmasıyla ilgili yeni bulgular elde edilebilmesi için kapsamlı yüzey araştırması ve sondaj kazılarına ihtiyaç duyulmaktadır.

Troas granit ocakları ve çevrelerinde yapılacak olası sondaj kazıları ile üretimde kullanılan araç ve gereçlere ait buluntuların tespit edilmesi olası bir durum olarak öngörülmektedir. Ayrıca taş ocaklarında çalışan işçilerin yaşam alanlarının belirlenmesi de mümkün olabilir. Bu ocaklarda üretim yapan işçiler, olasılıkla günümüz inşaat alanlarında bulunan şantiyelere benzer bir şekilde ocaklara yakın alanlarda barınma ihtiyaçlarını gideriyor olmalıydı. Taş ocağı işçilerinin ocaklara en yakın yerleşim yeri olan 13 km uzaklıktaki Aleksandreia Troas'a gidip gelmeleri çalışma saatlerini kısıtlayabilecek bir faktör ve yorucu bir işlem olmasına karşı üretilmiş bir çözüm olarak bu öneriyi desteklemek mümkündür. Bunun yanında Akçakeçili Ocağı'nın 200 m batısındaki ve Koçali Ocağı yakınlarında, taş ocağı işçilerinin yaşam alanları olabilecek yapı kalıntıları bu önermenin en önemli dayanağını oluşturmaktadır (Resim 18).

Troas Bölgesi'nde gerçekleştirilen araştırmalarda, Troas granit ocaklarının Roma İmparatorluk Dönemi'nden başlayarak Geç Roma Dönemi'ne kadar sütun üretimi için kullanıldığını gösteren üretim yöntemleri tespit edilmiştir (Ponti 1995: 291-320). Ayrıca ocakların çevrelerinde (Böhlendorf Arslan 2012: 435) ve limanda gerçekleştirilen çalışmalarda (Feuser 2011: 269) Erken Bizans Dönemi'ne tarihlenen çok sayıda seramik ele geçmiştir. Troas granit ocaklarının M.Ö. 4. ve M.S. 4. yüzyıl aralığında işletilmiş olduğunu gösteren analiz sonuçları mevcut olup (Yavuz 2014: 509), bu ocaklardan ihraç edilen granit sütunların kullanıldığı yapıların inşa tarihleri de analiz sonuçlarını desteklemektedir. Ancak Troas granit ocakları hakkında İmparator Theodosius'un yayınladığı iki kararname, ocakların neredeyse M.S. 5. yüzyılın 2. çeyreğine kadar redemptor operis ${ }^{1}$ 'ler tarafindan işletildiğini işaret etmektedir. Ayrıca bu kararnameler ile Troas granit ocaklarının işletmesinin imparatorluk idaresine geçtiği anlaşılmaktadır. Bölgedeki granit ocaklarının bulunduğu alanlarda M.S. 6. yüzyıla tarihlenen seramik buluntuların ele geçiyor olması ocakların kararnameler sonrasında da işletildiğini işaret etmektedir. Bunun dişında bu kararnameler sonrasında ocaklardaki üretimin yerel üretime dönüşmüş olma olasılığı da bulunmaktadır. Troas granit ocaklarında üretilen sütunların esas olarak Roma İmparatorluğu eyaletlerinde

1 Redemptor operis: Müteahhit, yüklenici, üstlenici (Berger 1953: 670). 
yer alan kentlere ihraç edildiği göz önüne alındığında ve Roma imparatorluğunun M.S. 5. yüzyılda yaşadığı siyasi ve ekonomik krizler, bu ocakların M.S. 6. yüzyıl da terkedilmiş olabileceğini düşündürmektedir. Bu durumda Troas granit ocaklarının M.S. 6. yüzyıla dek işletildiğini ifade etmek de mümkündür. Bölgedeki granit ocaklarında ve bu ocaklarda üretilen sütunların ihraç edildiği Aleksandreia Troas limanında M.S. 6. yüzyıla tarihlenen seramik buluntuların ele geçmiş olması da ocaklardaki faaliyetlerin bu yüzyıla kadar devam ettiğine işaret eder. Dolayısıyla Troas granit ocaklarının olasılıkla Geç Roma-Erken Bizans Dönemi’nde terkedilmiş olmalarını öne sürmek mümkündür. 


\section{Kaynakça}

ADAMS, C. E. P. (2001). "Who Bore the Burden? The Organization of Stone Transport in Roman Egypt, in Mattingly", In: D. J and Salmon, J. (eds.), Economies Beyond Agriculture in the Classical World, London-New York,171-192.

AGUS, M.- vd. (2007). "I marmi colorati di Uthina (Tunisia)", In: G. Sotgiu, H. Ben Hassen, A. M. Corda (éds.), Fouilles archéologiques à Uthina (2001-2007), Rapport préliminaire de l'activité de recherche de l'Institut du Patrimoine de Tunis et de l'Université de Cagliari, Italie, 2 vols., Ortacesus (ca)-Tunis: 1, 375-394.

ALBUSTANLIOĞLU, T. (2011). Roma İmparatorluk Döneminde Mermer Ocakları Organizasyonu, Ankara: Bilgin Kültür Sanat Yayınları.

ALBUSTANLIOĞLU, T. (2013). "Roma İmparatorluk Mermer Ocaklarında Yazıt Kullanımı ve Bazı Ünik Örnekler”, Tarih Kültür ve Sanat Araştırmaları Dergisi, Vol. 2, No. 4, November, 57-76.

ASGARI, N.- DREW BEAR, T. (2002).“The Quarry Inscriptions of Prokonnesos”, In: J. J. Herrmann, N. Herz, R. Newman (eds.), ASMOSIA 5, Interdisciplinary Studies on Ancient Stone, London: Archetype Publications, 1-19.

ASLAN, R. (1998). "Zamanı Öğüten Taş: Troas'ın Granitleri”, Atlas Dergisi Sayı 61, İstanbul: Doğan Ofset Yayincilik,79-95.

BERGER, A. (1953) Encyclopedic Dictionary of Roman Law, Transactions of the American Philosophical Society; New Series, Volume 43, Part 2.

BINGÖL, O. (2004). Arkeolojik Mimari'de Taş, İstanbul; Homer Kitabevi.

BLEGEN, C. W. (1934). "Excavations at Troy 1933", American Journal of Archaeology, Vol: 38. 2, 223 248.

BORGHINI, G. (1989). Marmi Antichi, Matereiali della cultura artistica I, Roma, De Luca Edizoni D’Arte.

BÖHLENDORF-ARSLAN, B. (2012). "2010 Yılında Ezine, Bayramiç ve Ayvacık İlçelerinde Bizans Dönemi Yerleşmeleri”, 29. AST, Cilt 2, Ankara: 431-452.

CHOISEUL-GOUFFIER, Marie Gabriel Florent Auguste de(1842). Voyage pittoresque dans l'Empire Ottoman, Atlas II, Paris:

COOK, J. M. (1973). The Troad: An Archaeological and Topographical Study, Oxford:

ÇAKICI, H. (2015). Aklımda Kalan Kırıntılar, Ankara, Karina Yayınevi.

DODGE, H. (1988). "Decorative Stones for Architecture in The Roman Empire", Oxford: Journal of Archaeology, Vol. 7, Issue 1, 65-80.

DWORAKOWSKA, A. (1983). Qarries in Roman Provinces, Warsaw, Bibliotheca Antiqua 16.

FANT, J. C. (1989). Cavum Antrum Phrygia: the Organization and Operations of the Roman Imperial Marble Quarries in Phrygia, Oxford: British Archaeological Reports International Series 482.

FEUSER, S. (2009a). "Elaia ve Aleksandria Troia. İki Antik Limanın Arkeolojik, Sualtı Arkeolojik ve Jeofizik Yüzey Araşıırması", Mavi Paylaşım , 7. Sualtı Sporları ve Bilimleri Toplantısı, Kocaeli: 1-3 Mayis 2009, 18-28.

FEUSER, S. (2009b). Der Hafen von Alexandria Troas, Asia Minor Studien: Vol. 63, Bonn: Habelt.

FEUSER, S. (2011). "The Roman Harbour of Alexandria Troas, Turkey", The International Journal of Nautical Archaeology, Vol. 40. 2, 256-273.

GALETTI, G.- vd. (1992). "A First Characterization of the Most İmportant Granites Used in Antiquity", In: M. Waelkens, N. Herz, L. Moens (eds.), Ancient Stones: Quarrying, Trade and Provenance, Acta Archaeologica Lovaniensia Monographia 4, Leuven:167-178.

GNOLI, R. (1971). Marmora Romana, Roma. 
GRANT, M. (2000). Roma'dan Bizans’a, (çev. Z. Zühre İlkgelen), İstanbul.

GUIDOBONI, E. (1994). Catalogue of Ancient Earthquakes in the Mediterranean Area up to the 10th Century, Roma, Storia Geofisica Ambiente, Bologna.

HAUDENSCHILD, E. (2011). The Kestanbol Intrusion (Western Turkey) and its importance as a building stone: Application of cosmogenic 10 Be to archaeology, (Unpublished Master Thesis), University of Bern, Bern, İsviçre: 159.

HIRT, A. M. (2010). Imperial mines and quarries in the Roman world: organizational aspects 27 BC-AD 235, Oxford.

IŞIK, M. A. (1977). “Çanakkale-Koçali ve Akçakeçili Köyü Yakınlarındaki Granit Sütun Yatakları”, Türk Arkeoloji Dergisi, Sayı: XXIV-1, Ankara: Varol Matbaası, 125-135.

KARAGÖZ, Ş. (2005). Eskiçağ’ da Depremler, İstanbul: Türk Eskiçağ Bilimleri Enstitüsü Yayınları.

KAYAN, İ. (1977). “Türkiye’nin Ege ve Akdeniz Kıyılarında Deniz Seviyesi ve Kıyı Çizgisi Değişmeleri”, Türkiye'nin Kıyı ve Deniz Alanları I. Ulusal Konferansı, Türkiye Kıyıları 97 Konferansı Bildiriler Kitab1, 735-746.

LANDELS, J. G.(1996). Eski Yunan ve Roma'da Mühendislik, (çev. Barış Bıçakçı), Ankara: TÜBİTAK Popüler Bilim Kitapları 34.

LAZZARINI, L. (1987).“I graniti dei monumenti italiani e i loro problemi di deterioramento”, In: A. Bureca, M. Laurenzi, Tabasso, G. Palandri (eds.), Materiali Lapidei II, Bollettino d'Arte Supplemento 41, Roma: 157-172.

LE CHEVALIER, J. B. (1791). Description of the plain of Troy, (translate: A. Dalzel), London.

MANGO, C. (1972). The Art of the Byzantine Empire 312-1453: Sources and Documents, Englewood Cliffs, N.J.: Prentice-Hall.

MANGO, C. (1976). Byzantine Architecture, New York.

MAXFIELD, V. A. (2001). "Stone Quarrying in the Eastern Desert with Particular Reference To Mons Claudianus and Mons Porphyrites", In: D.J. Mattingly And J. Salmon (eds.) Economies beyond Agriculture in the Classical World (Leicester-Nottingham Studies in Ancient Society, 9), LondonNew York: 143-170.

MIELSCH, H. (1985). Buntmarmor aus Rom im Antikenmuseum Berlin, Staatliche Museen Preussischer Kulturbesitz, Berlin.

MONNA, D.- PENSABENE, P. (1977). Marmi dell'Asia Minore, Rome.

NEWTON, C. T. (1865). Travels \& Discoveries-İn the Levant, Keeper of the Greek and Roman Antiquities, London: British Museum, Cambridge University Press.

OUSTERHOUT, R. (2016). Bizans'ın Yapı Ustaları, (çev. Fügen Yavuz), İstanbul: Koç Üniversitesi Yayınlar1.

PENSABENE, P. (1998). "Marmi d'importazione, pietre locali e committenza nella decorazione architettonica di età severiana in alcuni centri delle province Syria et Palaestina e Arabia", In: ArchCl 49, 175-422.

PENSABENE, P.- vd. (2015). "Production and distribution of Troad granite, both public and private", In: P. Pensabene, E. Gasparini (eds.), Interdisciplinary Studies on Ancient Stone, ASMOSIA X, Proceedings of the Tenth International Conference of ASMOSIA, Association for the Study of Marble \& Other Stones in Antiquity Rome, 21-26 May 2012, 311-322.

PONTI, G. (1995). "Marmor Troadense-Granite Quarries in The Troad: A Preliminary Survey", Studia Troica 5, 291-320.

REYNOLDS, J. M. - WARD-PERKINS, J. B. (1952). The Inscriptions of Roman Tripolitania, In collaboration with S. Aurigemma, R. Bartoccini, G. Caputo, R. Goodchild, P. Romanelli, Roma. 
ROSE, C. B. (1992). "The 1991 Post-Bronze Age Excavations at Troia”, In: Korfmann, M. (ed.) Studia Troica 2, 43-60.

RUSSELL, B. (2013). The Economics of Roman Stone Trade, Oxford Studies on the Roman Economy, New York: Oxford University Press.

SCHLIEMANN, H. (2014). Troya'dan İda Dağı'na Troas'ta Yolculuk, (çev. İlhan Pınar), İstanbul: Say Yayınları.

SODINI, J.-P. (2002). "The Economic History of Byzantium: From the Seventh through the Fifteenth Century", in: (ed.) Angeliki E. Laiou, The Economic History of Byzantium, Dumbarton Oaks Research Library and Collections 39, Vol.: 1, Part: 1, Washington D. C.: 129-146.

SONNABEND, H. (1999). Naturkatastrophen in der Antike, Wahrnehmung-Deutung-Management, Stuttgart: Weimar.

TEXIER, C. (2002). Küçük Asya - Coğrafyası, Tarihi ve Arkeolojisi, Cilt III, (çev. Ali Suat), Ankara: Enformasyon ve Dokümantasyon Hizmetleri Vakfi.

TOMBUL, M. (2015). Çanakkale Kültür Envanteri: Arkeolojik Yerleşim Alanları ve Sanat Tarihi Yapıları, T.C. Çanakkale Valiliği.

VITRUVIUS (1990). Mimarlık Üzerine On Kitap, (çev. S. Güven), İstanbul: Şevki Vanlı Mimarlık Vakfı Yayınları.

WARD - PERKINS J. B. (1980). "Nicomedia and the Marble Trade", Papers of the British School of Rome 48, 23-68.

YAVUZ, E. V. (2014).“Antique Quarries of Marmor Troadense (NW Turkey): İnsights From Field Mapping and Absolute Dating", Turkish Journal of Earth Sciences 23, 495-512. 


\section{Ekler}

\section{Haritalar}

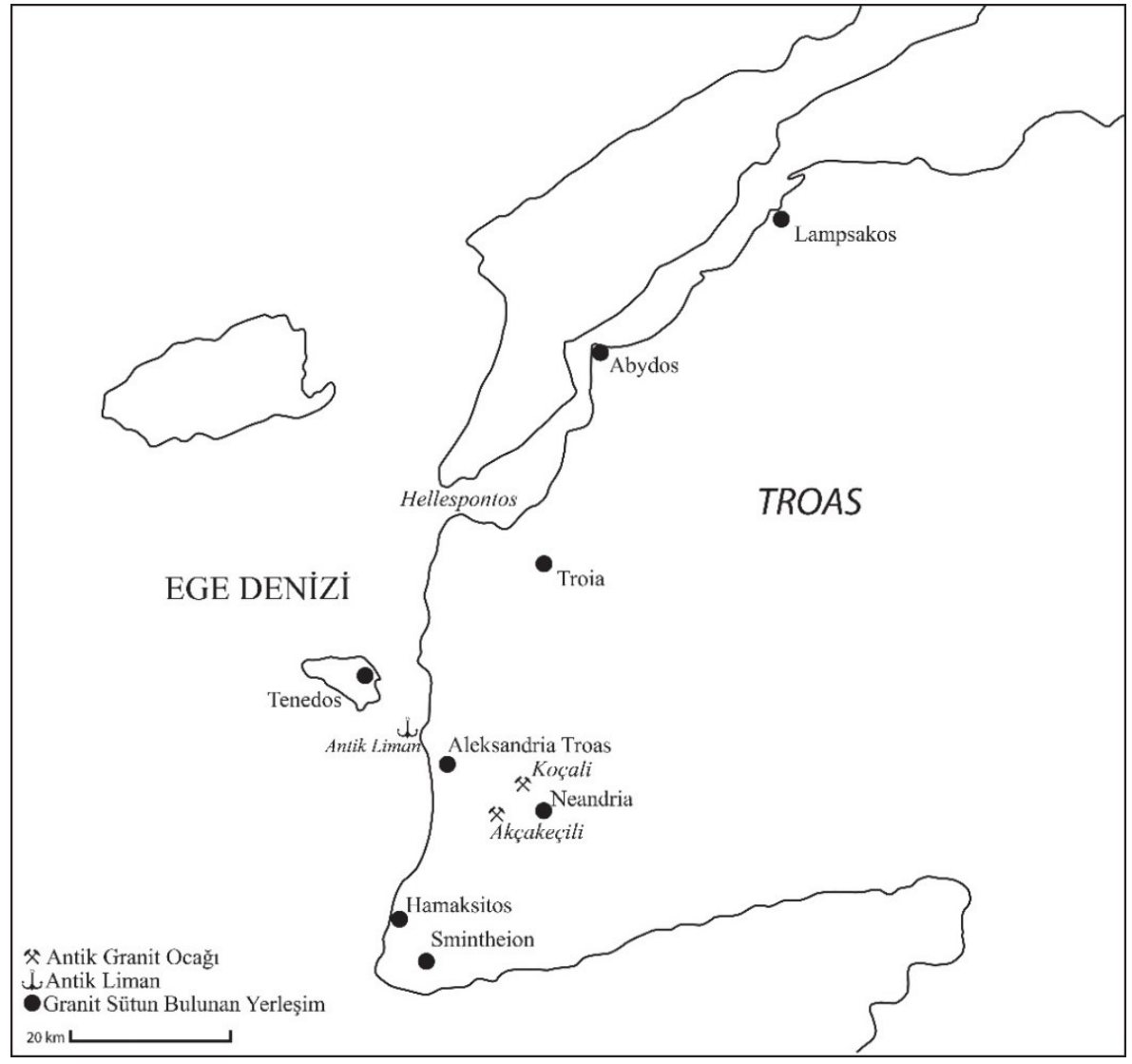

Harita 1. Troas Bölgesi'ndeki Koçali ve Akçakeçili ocağı ile granit sütun bulunan yerleşimlerin konumları. 


\section{Resimler}

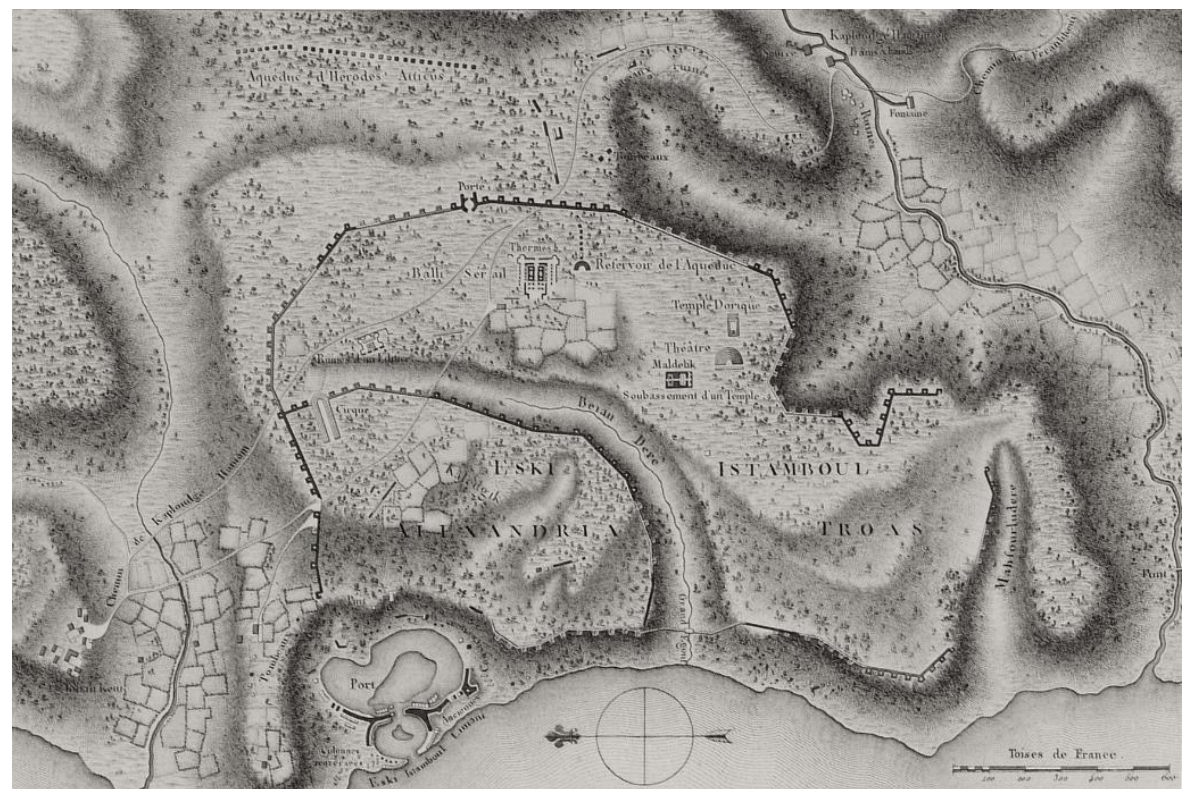

Resim 1. Aleksandreia Troas'1n kent planı (Choiseul-Gouffier 1842: Tab. 39).

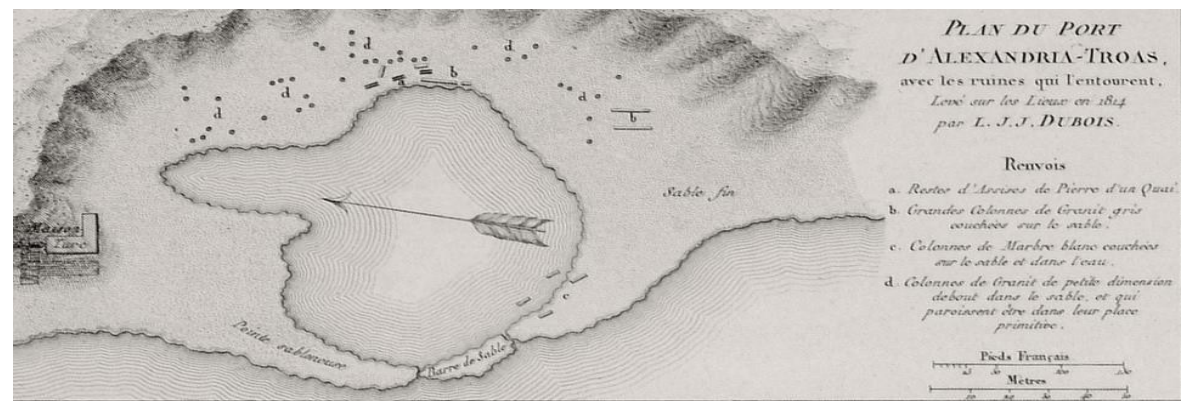

Resim 2. Aleksandreia Troas'ın liman planı (Choiseul-Gouffier 1842: Tab. 44). 


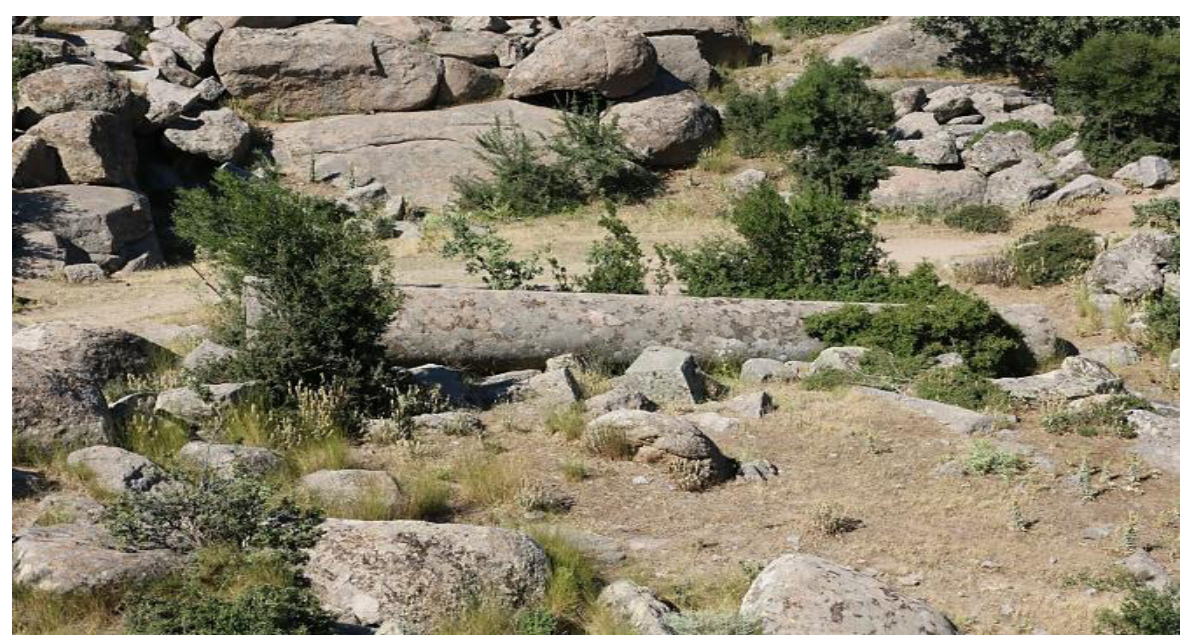

Resim 3. Koçali Ocağı'nın girişinde yer alan ocak ve sütunlar.

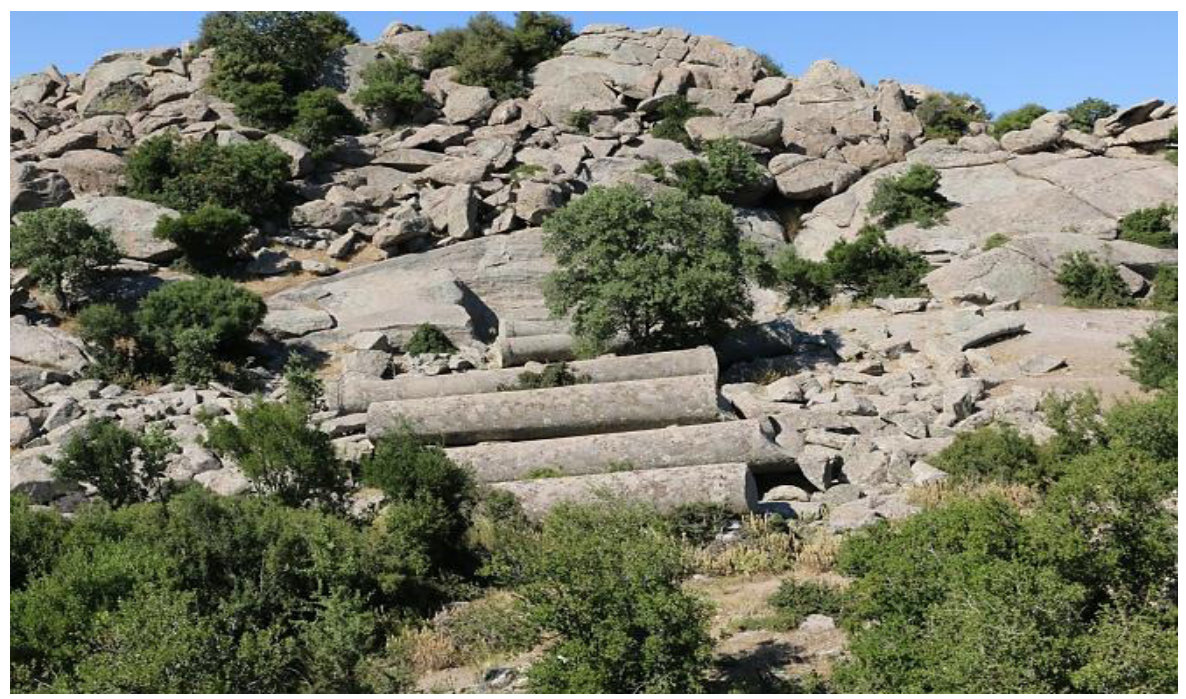

Resim 4. Koçali Ocağı'nın cepheden görünümü. 


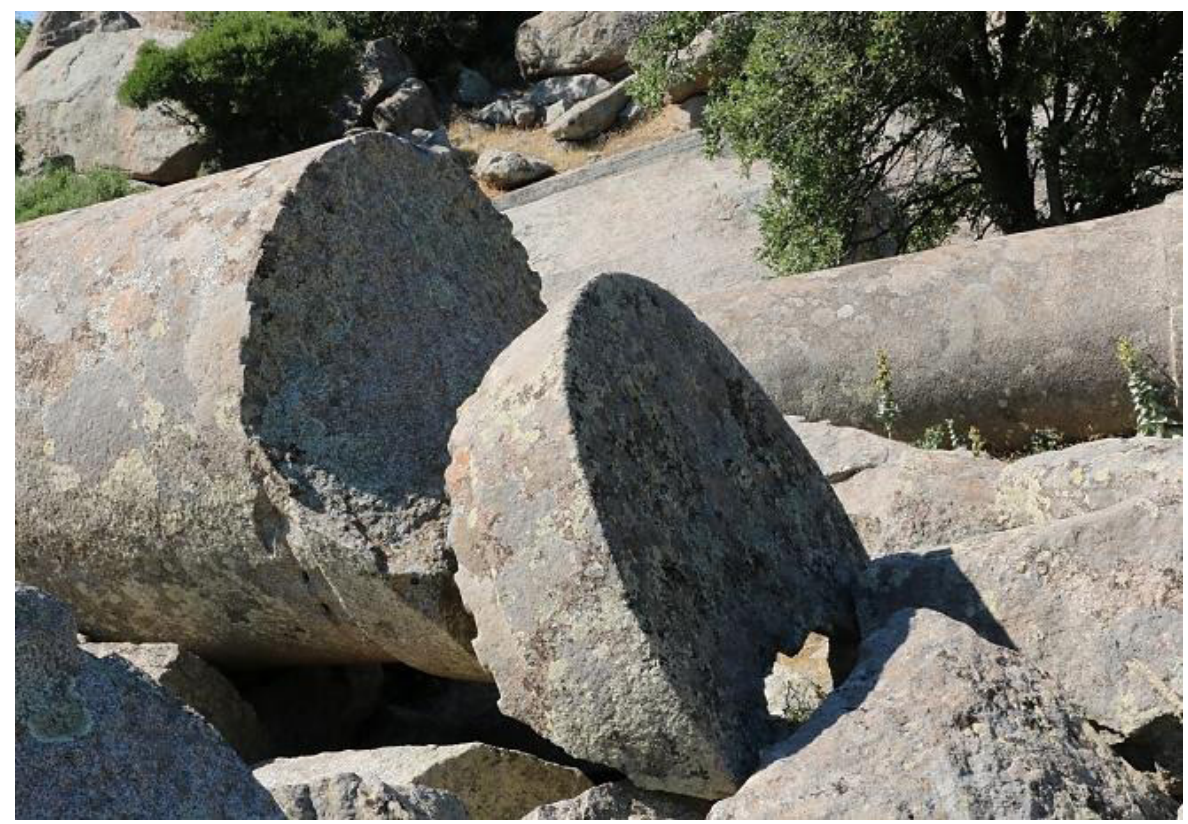

Resim 5. Koçali Ocağı planındaki alt bölümü tahrip edilmiş olan 5 numaralı sütun.

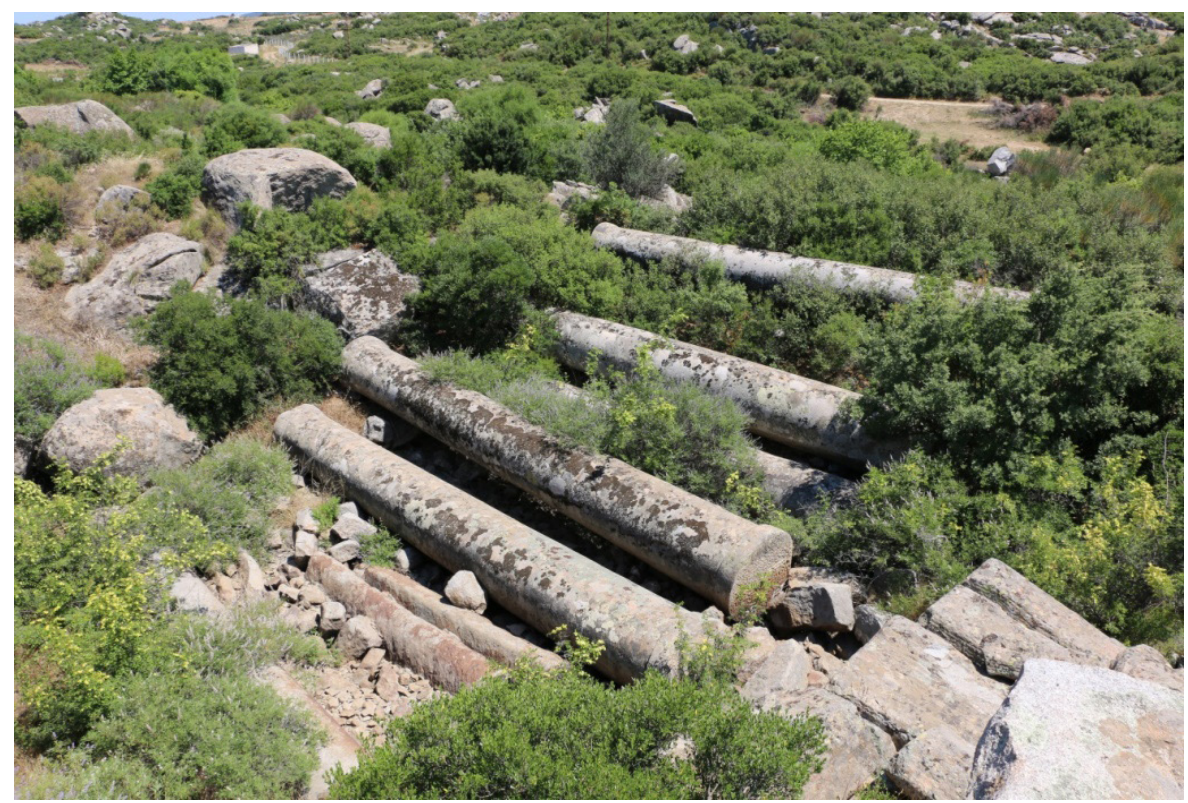

Resim 6. Akçakeçili Ocağı'nın görünümü. 


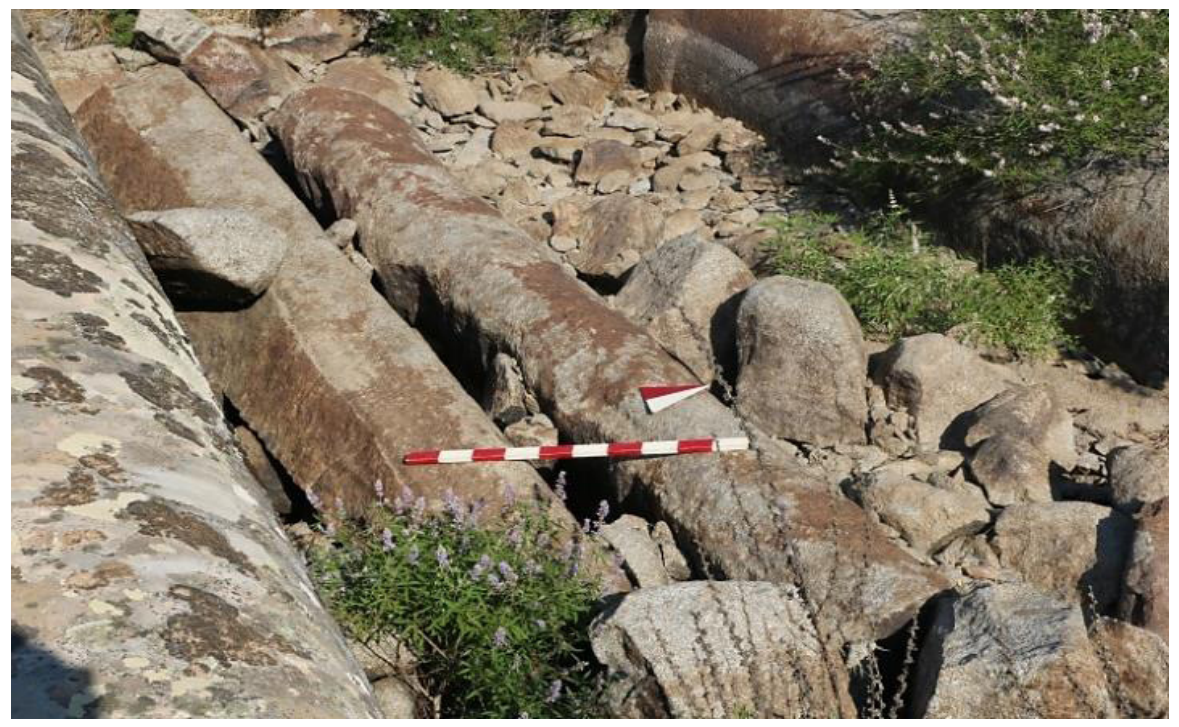

Resim 7. Akçakeçili Ocağı'nda kabaca işlenmiş olan küçük boyutlardaki sütunlar.

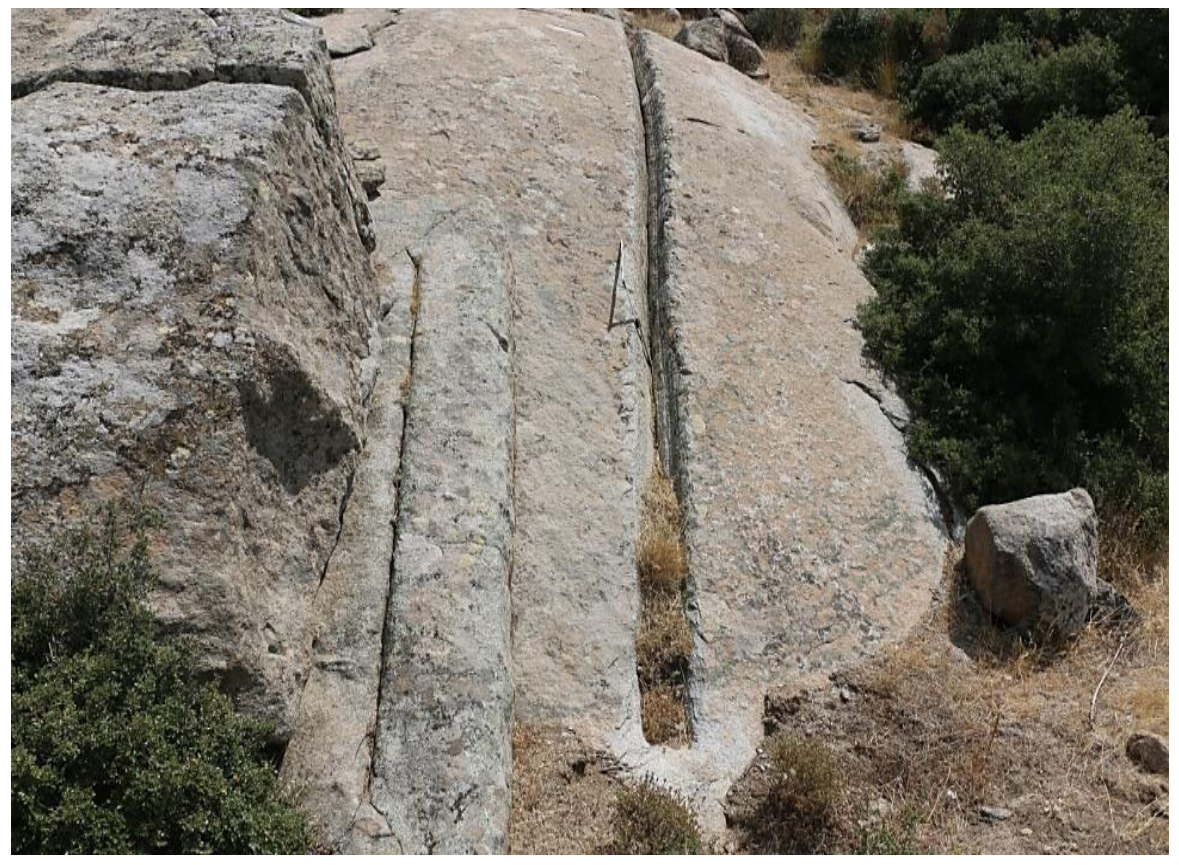

Resim 8. Sütun üretim faaliyetlerine ve oluk-kanal açma yöntemine ait izler. 


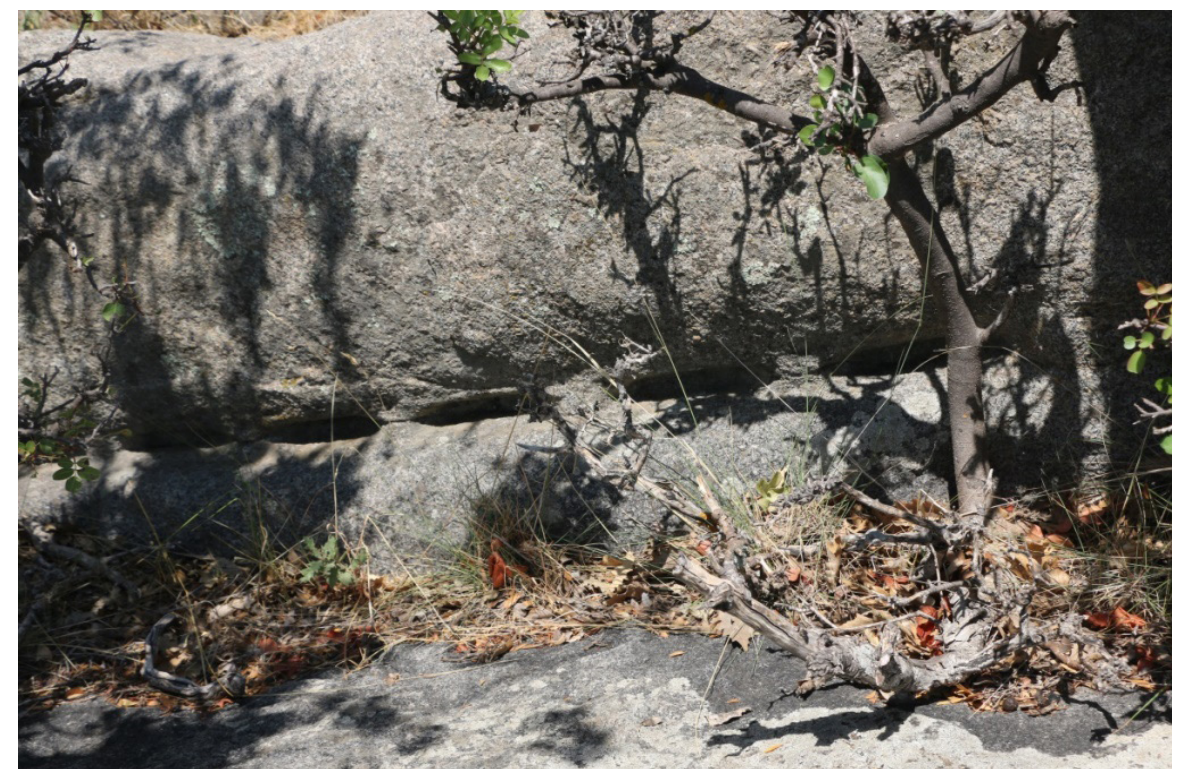

Resim 9. Koçali Ocağı'nın batısında yer alan ocakta görülen kama ile sütun çıkarma yöntemine ait izler.

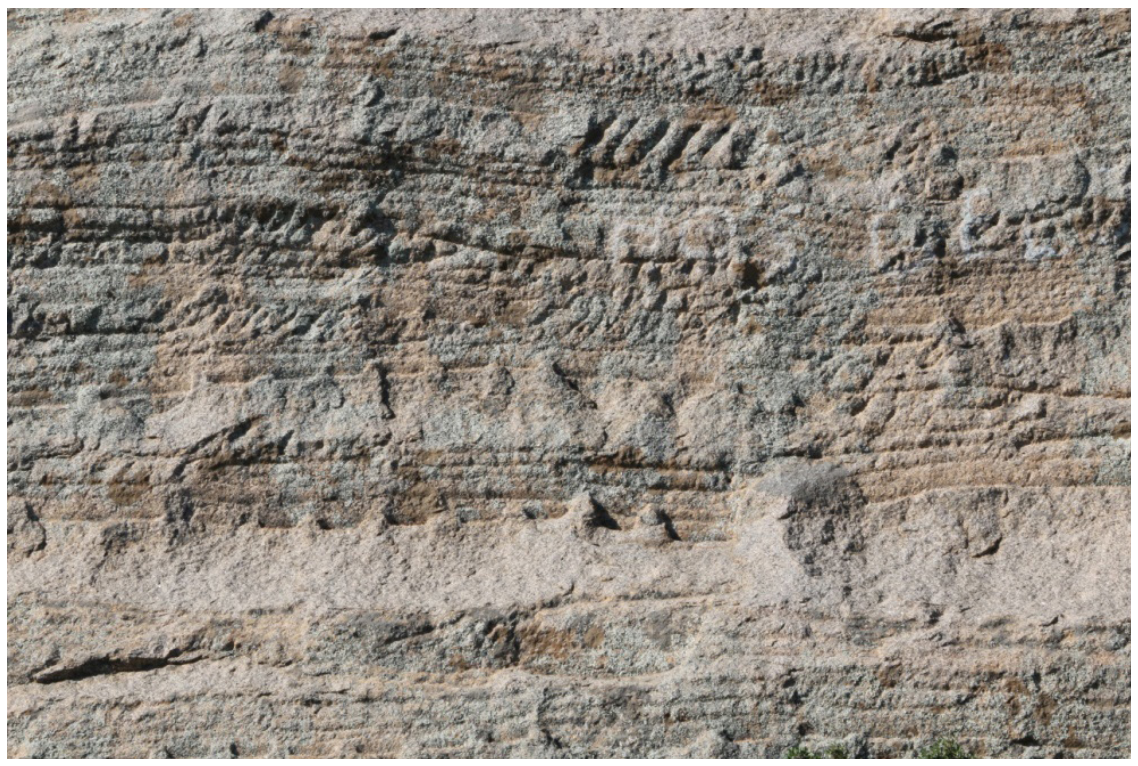

Resim 10. Koçali Ocă̆ı’’nın yüzeyindeki kazıma ve kama izleri. 


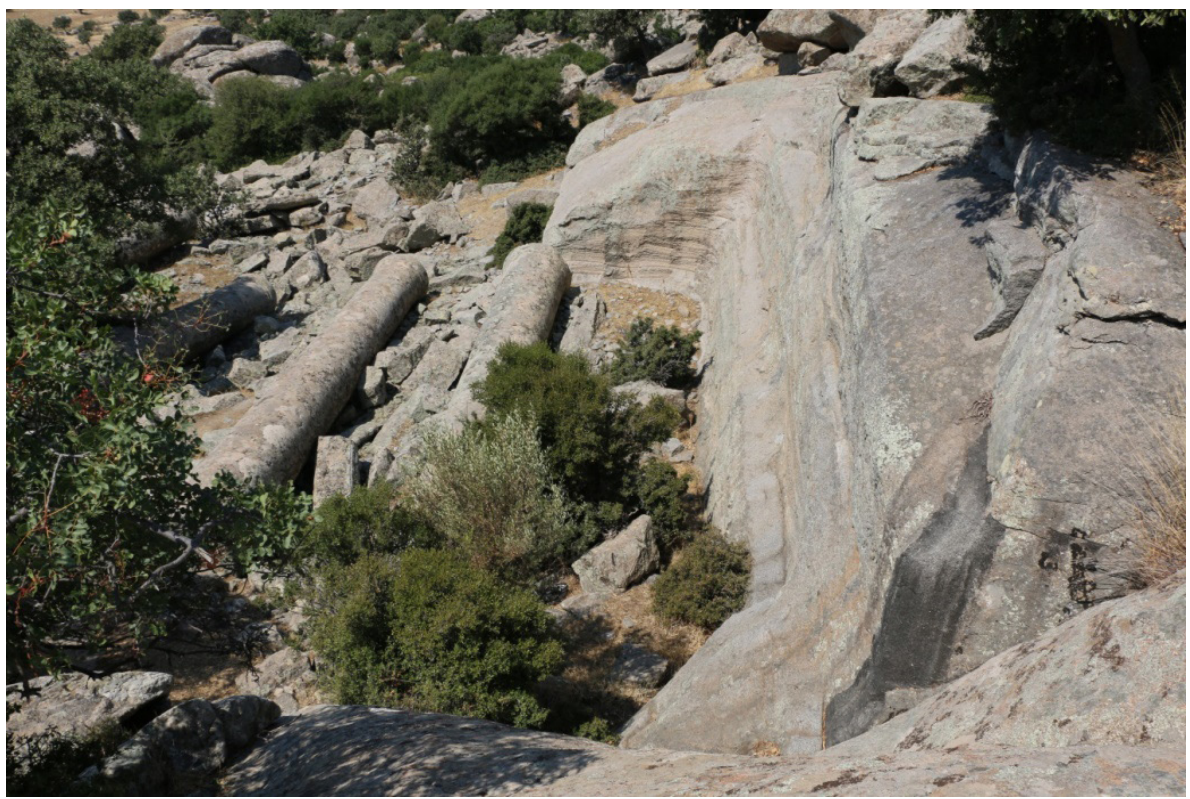

Resim 11. Koçali Ocağı'nın yüzeyinde görülebilen kademeli sütun çıkarma izleri.

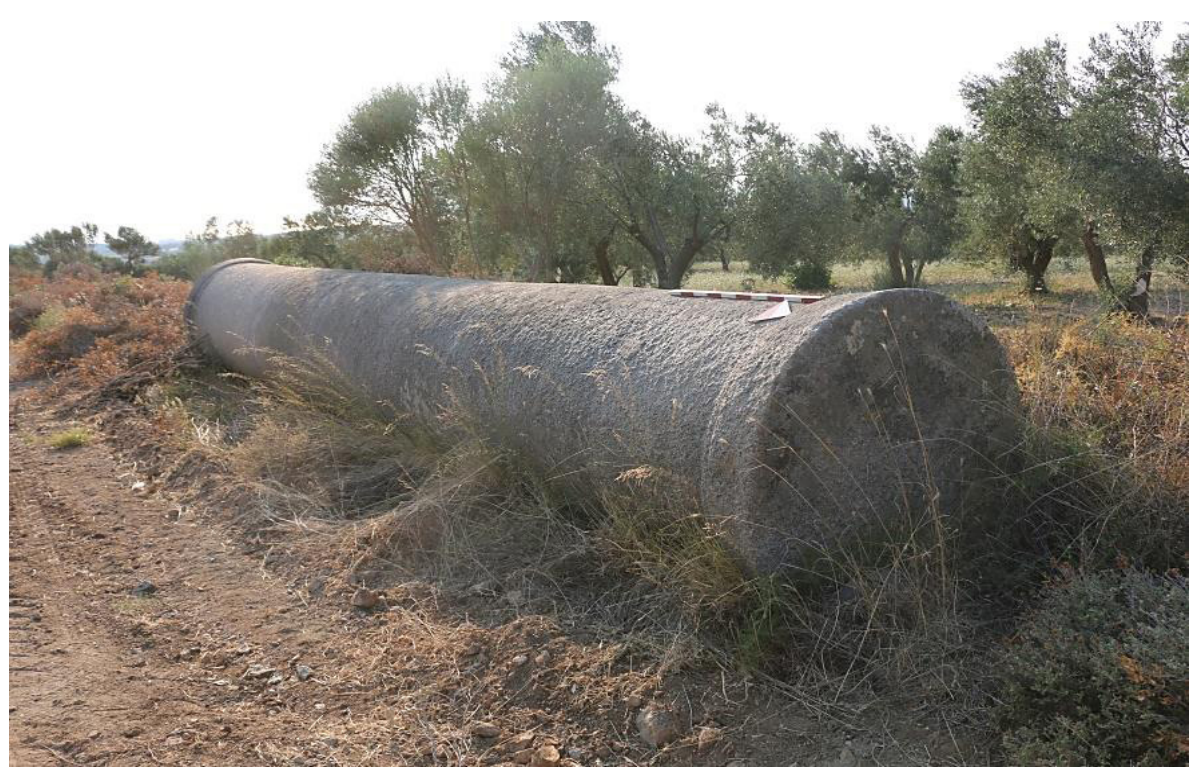

Resim 12. Kemallı Köyü mevkiindeki antik yolun kenarında yer alan yekpare sütun. 


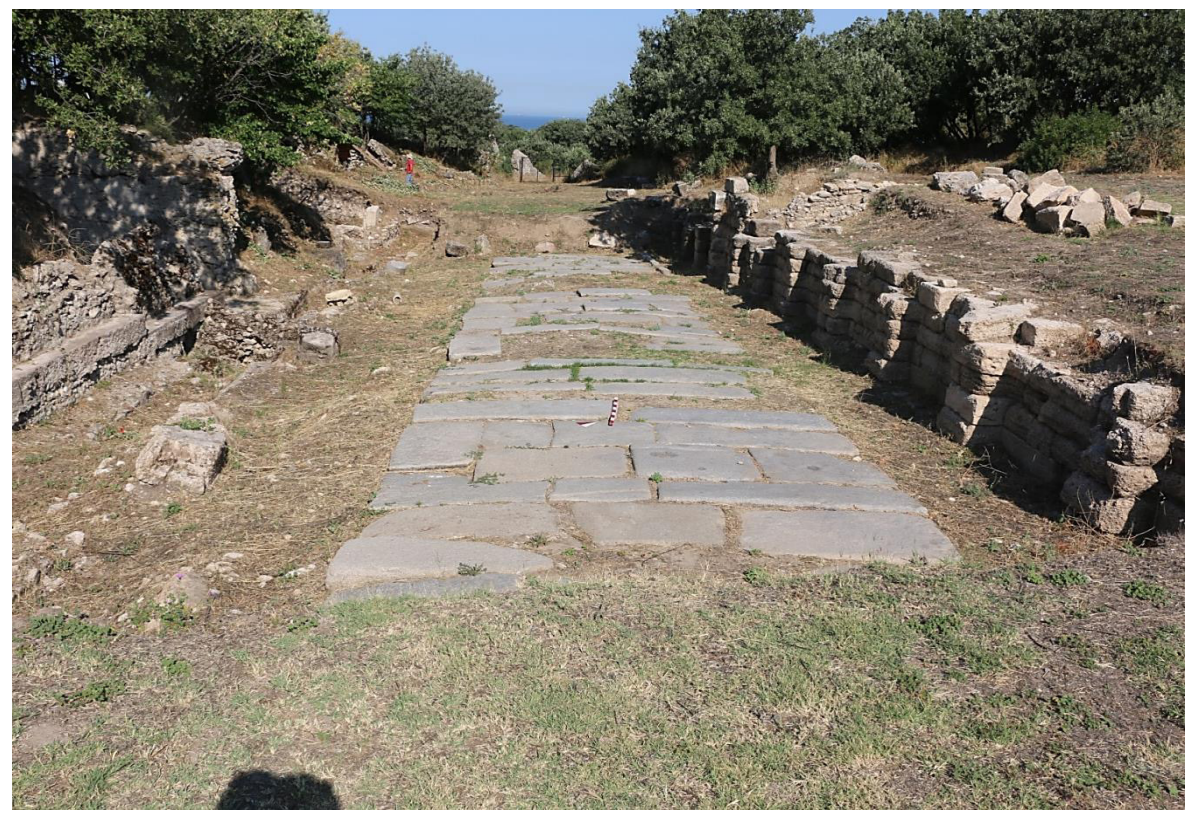

Resim 13. Aleksandreia Troas'ın forum alanındaki Decumanus Caddesi.

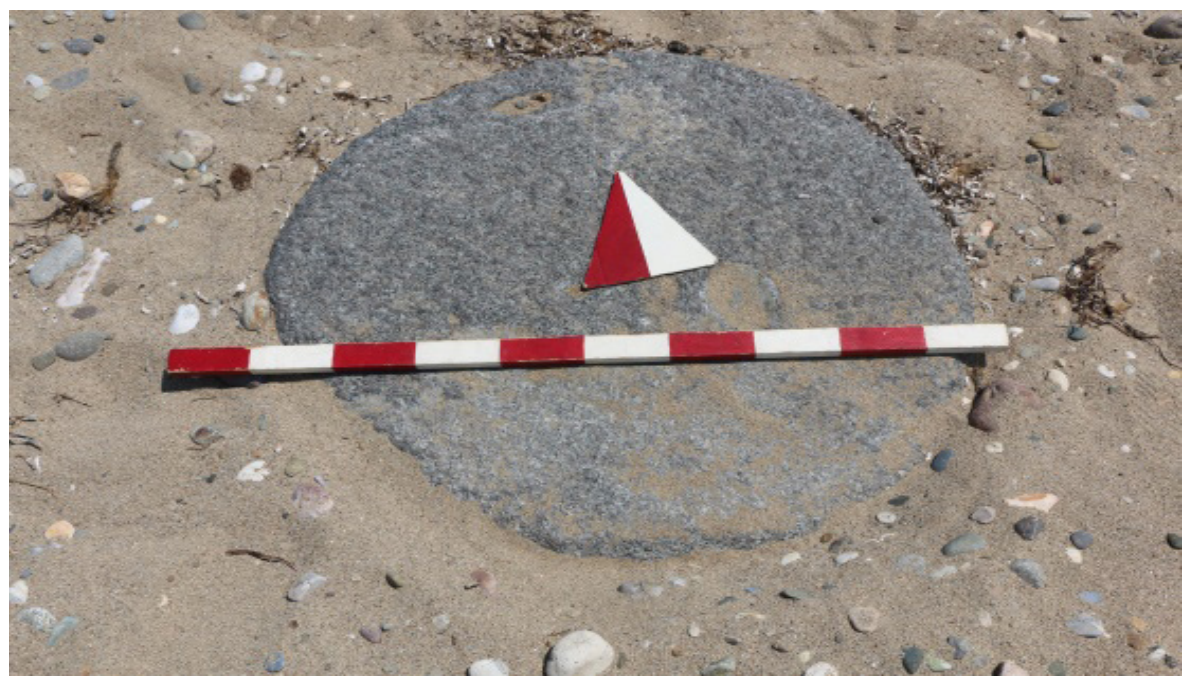

Resim 14. Antik limanda kumlarla örtülmüş haldeki sütun parçası. 


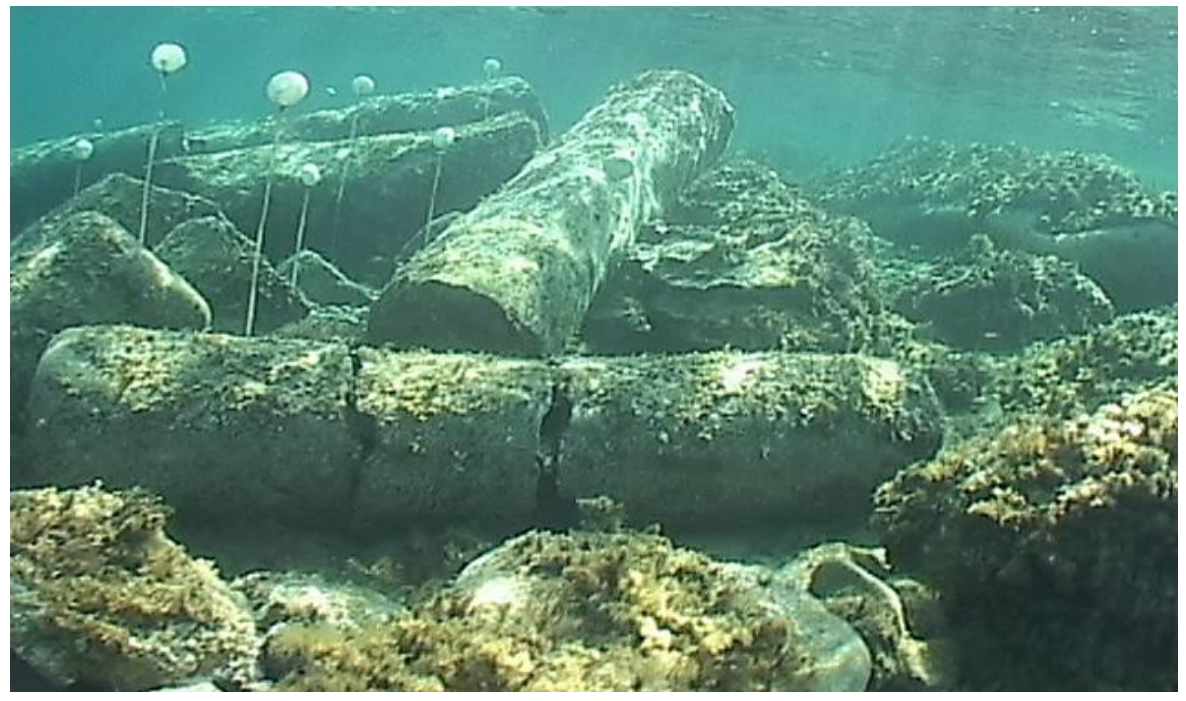

Resim 15. Antik limanda denize düşmüş olan granit sütun ve bloklar (A. Onur Bamyacı).

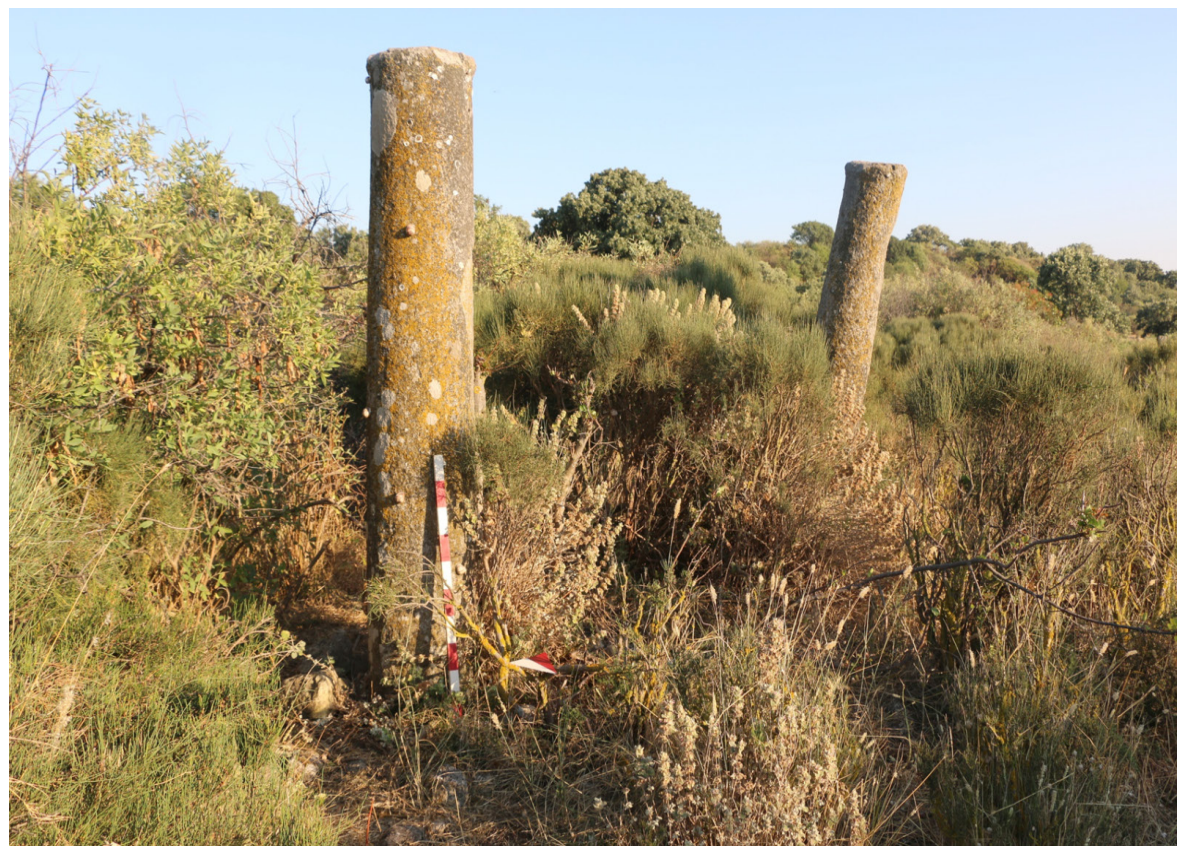

Resim 16. Antik liman çevresindeki in situ durumdaki sütunlar. 


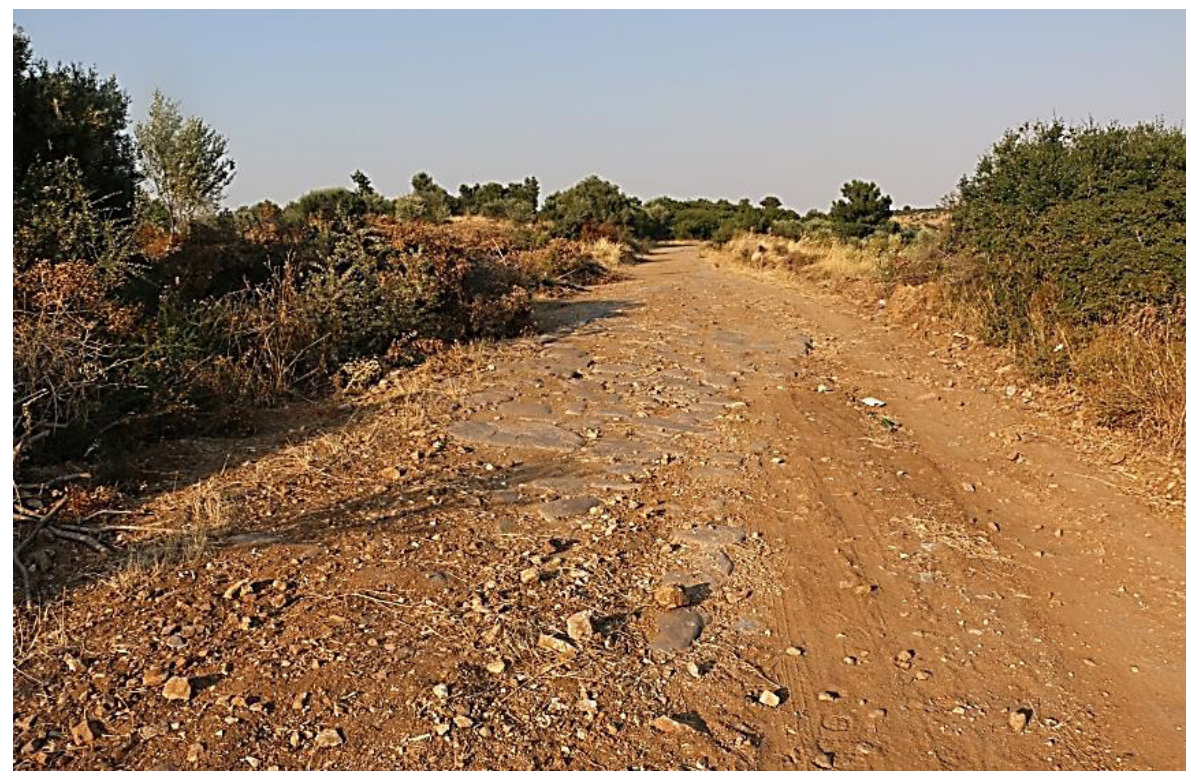

Resim 17. Kemallı Köyü mevkiindeki granit döşeme taşlı antik yol.

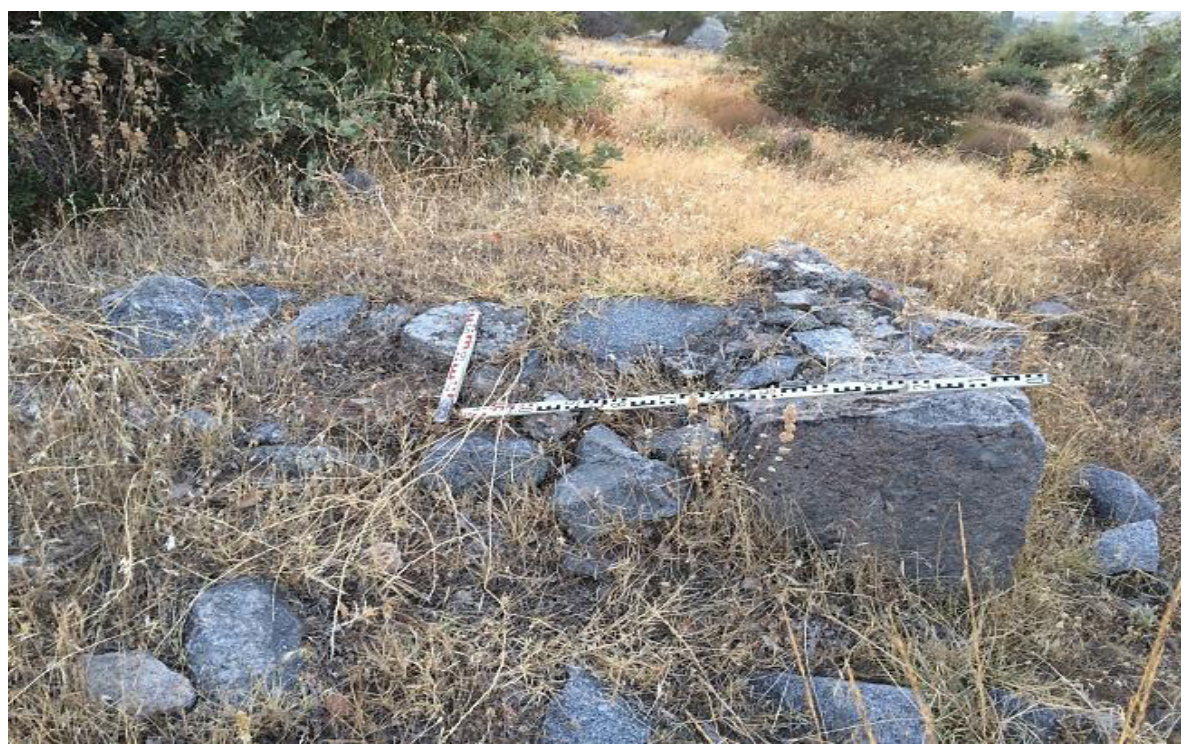

Resim 18. Koçali Ocağı civarındaki mimari yapı kalıntıları. 


\section{Çizimler}

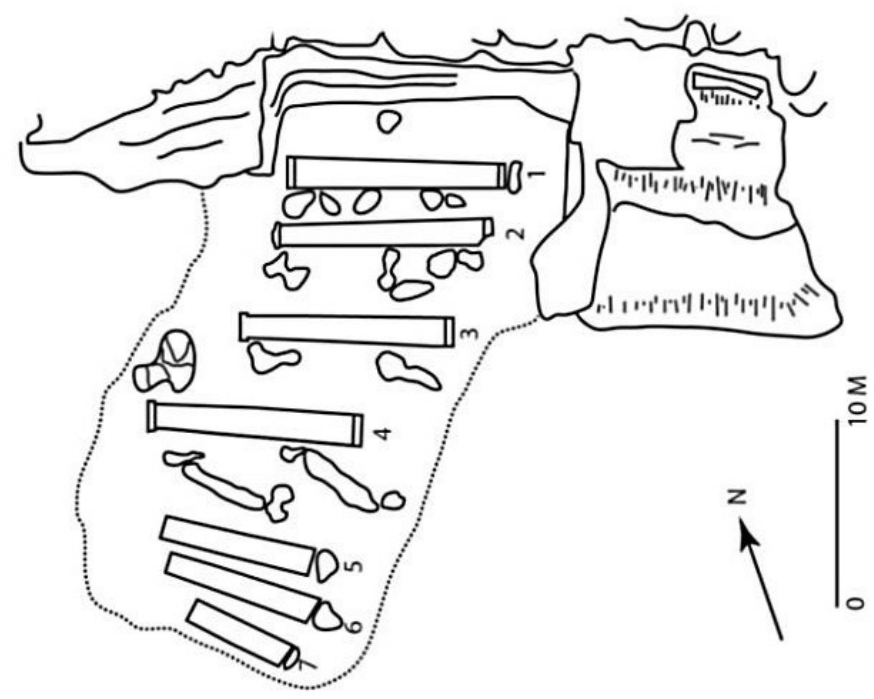

Çizim 1. Koçali Ocağı'nın planı (Ponti 1995: Plate 3). 


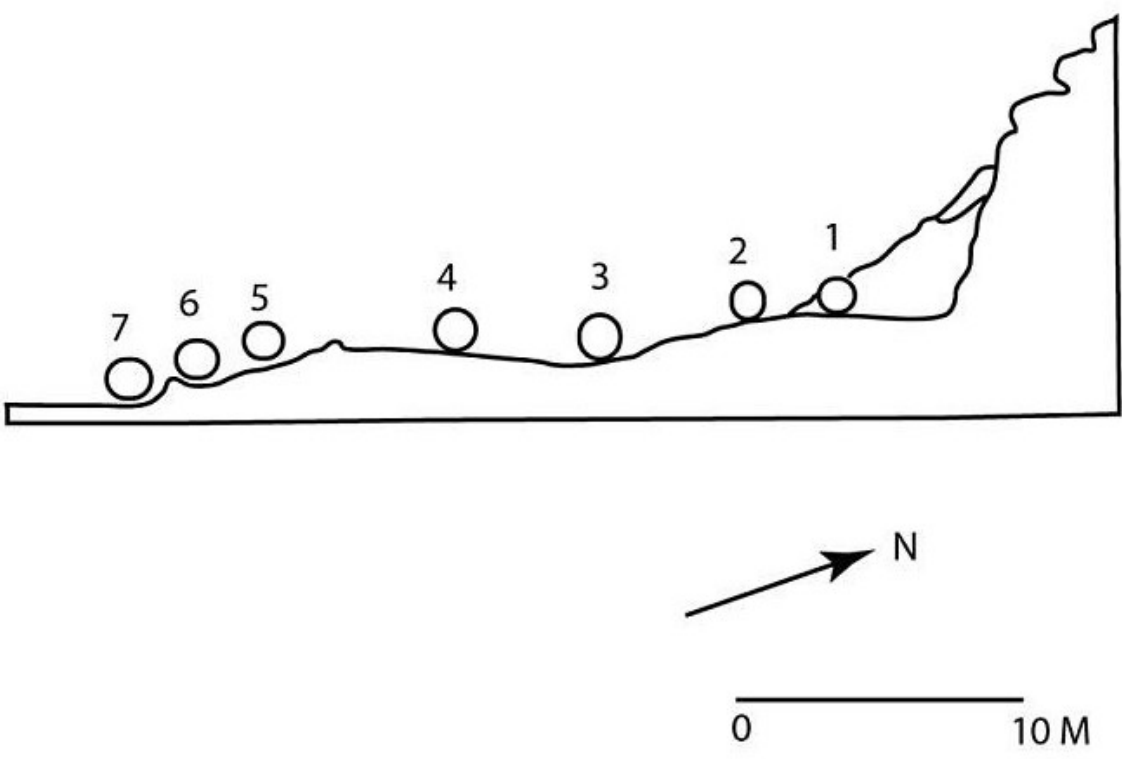

Çizim 2. Koçali Ocağı'nın kesiti (Ponti 1995: Plate 3). 


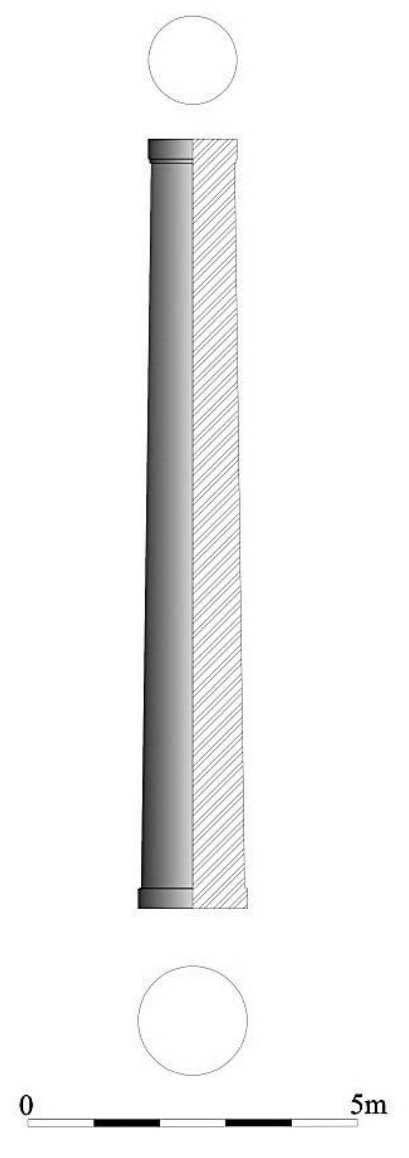

Çizim 3. Koçali Ocağı'ndaki 1 numaralı sütuna ait çizim. 


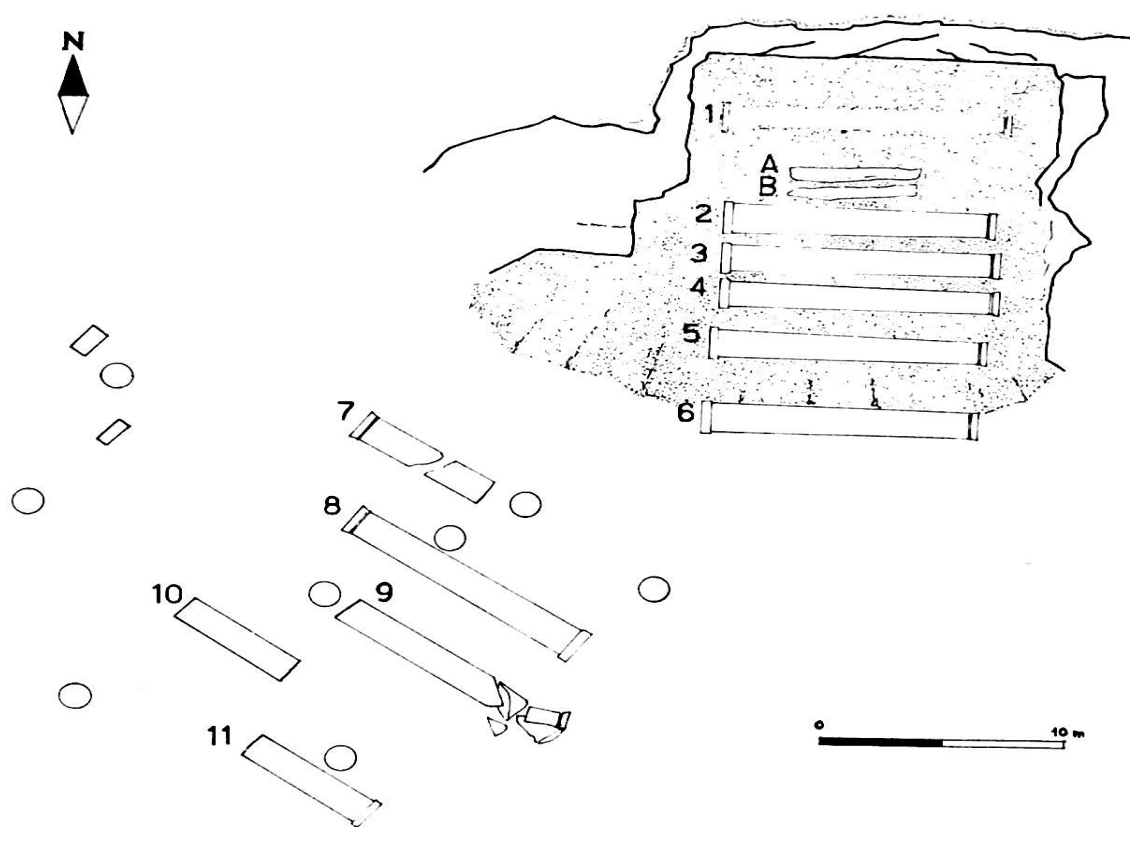

Çizim 4. Akçakeçili Ocağı'nın planı, (Ponti 1995: Plate 6). 